\title{
Mitochondrial oxidative stress in obesity: role of the mineralocorticoid receptor
}

\author{
Clara Lefranc', Malou Friederich-Persson ${ }^{2, *}$, Roberto Palacios-Ramirez ${ }^{1, *}$ and Aurelie Nguyen Dinh Cat ${ }^{1}$ \\ IINSERM, UMRS 1138, Centre de Recherche des Cordeliers, Pierre et Marie Curie University, Paris Descartes University, Paris, France \\ 2Medical Cell Biology, Uppsala University, Uppsala, Sweden \\ Correspondence should be addressed to A Nguyen Dinh Cat: cattuong.ndc@gmail.com \\ *(M Friederich-Persson and R Palacios-Ramirez contributed equally to this work)
}

\section{Abstract}

Obesity is a multifaceted, chronic, low-grade inflammation disease characterized by excess accumulation of dysfunctional adipose tissue. It is often associated with the development of cardiovascular (CV) disorders, insulin resistance and diabetes. Under pathological conditions like in obesity, adipose tissue secretes bioactive molecules called 'adipokines', including cytokines, hormones and reactive oxygen species (ROS). There is evidence suggesting that oxidative stress, in particular, the ROS imbalance in adipose tissue, may be the mechanistic link between obesity and its associated CV and metabolic complications. Mitochondria in adipose tissue are an important source of ROS and their dysfunction contributes to the pathogenesis of obesity-related type 2 diabetes. Mitochondrial function is regulated by several factors in order to preserve mitochondria integrity and dynamics. Moreover, the renin-angiotensin-aldosterone system is over-activated in obesity. In this review, we focus on the pathophysiological role of the mineralocorticoid receptor in the adipose tissue and its contribution to obesity-associated metabolic and CV complications. More specifically, we discuss whether dysregulation of the mineralocorticoid system within the adipose tissue may be the upstream mechanism and one of the early events in the development of obesity, via induction of oxidative stress and mitochondrial dysfunction, thus impacting on systemic metabolism and the CV system.

\author{
Key Words \\ - mineralocorticoid \\ receptor \\ - adipose tissue \\ - mitochondrial dysfunction \\ - oxidative stress \\ - obesity
}

\section{Introduction}

Obesity is a chronic inflammatory disease with an ever-increasing prevalence. Excessive and ectopic fat accumulation leads to adverse health effects and reduced life span. Obesity is originally defined by the BMI $\left(\mathrm{BMI}=\right.$ weight height $\left.^{2}\right)$. A person is considered obese when their BMI exceeds $30 \mathrm{~kg} / \mathrm{m}^{2}$ (http://www.who.int/ news-room/fact-sheets/detail/obesity-and-overweight). However, this index does not evaluate lean-to-fat mass ratio. Adiposity is more precisely evaluated by taking into account the body fat distribution, using the waist circumference or waist-to-hip ratio.

The high mortality and morbidity rates associated with obesity worldwide are largely attributed to cardiovascular (CV) complications (Pischon et al. 2008). Obesity and obesity-associated metabolic and $\mathrm{CV}$ risk factors are grouped under the term 'cardiometabolic syndrome' (CMS), including hypertension, dyslipidemia and type 2 diabetes (T2D) (Alberti et al. 2009). 
Accumulated adipose tissue, in obesity, stimulates the synthesis of pro-inflammatory cytokines, as well as bioactive substances called 'adipokines', which increase generation of reactive oxygen species (ROS) (FernándezSánchez et al. 2011). Indeed, inflammation, oxidative stress and mitochondrial dysfunction contribute to the pathogenesis of metabolic disorders, including insulin resistance and T2D (Furukawa et al. 2004, Bournat \& Brown 2010, Sivitz \& Yorek 2010, Montgomery \& Turner 2014).

During the past decade, several studies have reported the importance of aldosterone and the mineralocorticoid receptor (MR) in CMS (Zennaro et al. 2009, Whaley-Connell et al. 2010, Ronconi et al. 2012, Even et al. 2014). Increasing evidence shows a link between obesity, hypertension and hyperaldosteronism, and clinical studies have established a positive correlation between visceral obesity, CMS or BMI and plasma levels of aldosterone (Goodfriend et al. 1999, Fallo et al. 2006, Ingelsson et al. 2007, Rossi et al. 2008). Aldosterone mediates deleterious effects in adipose tissue through genomic and non-genomic pathways, leading not only to alteration of glucose metabolism and insulin sensitivity (Luo et al. 2013, Feliciano Pereira et al. 2014, Luther 2014, Marzolla et al. 2014, Urbanet et al. 2015), but also to inflammation, oxidative stress, endothelial dysfunction and vasoconstriction, as adipose tissue is intimately associated with structural and physiological functions of the vasculature (Guo et al. 2008, Tirosh et al. 2010, Nguyen Dinh Cat et al. 2016).

Little is known of how the mineralocorticoid system regulates obesity-associated oxidative stress and mitochondrial dysfunction. In this review, we focus on factors and pathways in adipose tissue, which link oxidative stress and/or mitochondrial dysfunction to MR activation. Such factors/pathways could represent new, interesting therapeutic targets and give relevance to the use of MR antagonists in the prevention and/or attenuation of metabolic and vascular disorders that occur in CMS.

\section{Adipose tissue dysfunction in obesity}

\section{Adipose tissue expansion}

Adipose tissue is a metabolically dynamic organ, playing an essential role in regulating energy balance. This is achieved by storing triglycerides in periods of energy excess and mobilizing energy in the form of fatty acids, available to meet the energy requirements of other tissues, during fasting. White adipose tissue (WAT) is composed of perivascular, subcutaneous (scWAT) and visceral (vWAT) adipose tissue, which, in turn, is divided in epicardial, perirenal, gonadal, retroperitoneal, omental and mesenteric fat. These fat depots display distinct characteristics, as well as clear differences in fatty acid storage and release and inflammatory profile. Thus, it is likely that these depots play specific roles in the regulation of whole body energy homeostasis (Tchkonia et al. 2013).

In obesity, adipose tissue undergoes remodeling, observed as changes in the number (hyperplasia) and/or size (hypertrophy) of the adipocytes. Such remodeling determines the CV and metabolic outcomes of the disease (Spiegelman \& Flier 1996). Progenitor cells (preadipocytes) are eight-fold more abundant in scWAT than vWAT, which could explain the propensity of visceral adipocytes to become overloaded and thus resistant to insulin and to triglycerides storage (Joe et al. 2009, Kim et al. 2015, Choe et al. 2016). Indeed, vWAT expansion by hypertrophy predisposes to diabetes, insulin resistance and CV diseases, whereas growth of scWAT by hyperplasia may actually be protective, enabling this depot to act as a buffer for lipid excess, and thus protecting other tissues (heart, liver, skeletal muscle) from fatty infiltration (Wajchenberg 2000, McLaughlin et al. 2011). This variability among WAT depots seems to be already determined at the preadipocyte stage, as specific and different expression patterns of developmental genes have been described in stromal vascular fraction from scWAT, compared to the ones from vWAT. These depotspecific differences are maintained during adipogenesis (Gesta et al. 2006).

\section{Brown adipose tissue activity and WAT browning in obesity}

In humans, brown adipose tissue (BAT) is predominantly found in the neck, supraclavicular and paraspinal regions, and its activity is inversely correlated with BMI (van Marken Lichtenbelt et al. 2009). Activation of the thermogenic BAT has beneficial effects on adiposity and insulin resistance, through activation of mitochondrial uncoupling protein UCP1 that allows the dissipation of energy in the form of heat (Lowell et al. 1993, Poher et al. 2015). Adipocytes from WAT can undergo the process of browning (also known as beiging) in response to stimuli such as cold exposure, exercise, fasting or specific drug treatments (SIRT1 activators and $\beta 3$-adrenergic receptor (33-AR) agonists) (Cypess et al. 2015, Stanford et al. 2015, Li et al. 2017, Thyagarajan \& Foster 2017). These 'beige' adipocytes possess a unique molecular phenotype with expression of brown adipocytes genes (Ucp1, Cidea), as 
well as genes that are strictly specific to beige adipocytes, including Tbx1 and Slc27a1 (Wu et al. 2012). Browning of WAT is often associated with increased energy expenditure and decreased lipid metabolism. Thus, promoting WAT browning could represent an alternative therapeutic strategy to combat obesity and its related metabolic disorders (Bartelt \& Heeren 2014, Thyagarajan \& Foster 2017).

However, the precise mechanism of browning induction is still unclear, as many browning agents have effects on metabolism or can induce heat loss. Thus, this is difficult to determine whether these agents have a direct mechanism of action or if browning is a secondary effect of metabolic modulations (Nedergaard \& Cannon 2014). Studies have reported that $\beta 3$-AR activation may be involved in WAT browning since deletion of $\beta 3$-AR gene in mice leads to impaired WAT browning (Feldmann et al. 2009). Moreover, UCP1 activity seems to be determining for obesity development, since UCP1-deficient mice display no diet-induced adrenergic thermogenesis and become obese even when fed with chow diet (Jimenez et al. 2003).

Of note, obesity also leads to BAT dysfunction with decreased $\beta$-adrenergic signaling, accumulation of enlarged lipid droplets and mitochondrial dysfunction. This process of 'BAT whitening' has been associated with vascular rarefaction due to decreased expression of vascular endothelial growth factor A (Vegfa) (Shimizu et al. 2014, Shimizu \& Walsh 2015).

\section{Adipose tissue as an endocrine organ}

Besides functioning as a storage organ, adipose tissue is a highly active endocrine organ and an important metabolic sensor. Apart from adipocytes, adipose tissue is composed of a wide variety of cells, including preadipocytes, fibroblasts, endothelial and vascular smooth muscle cells, nerve cells, as well as immune cells, including $\mathrm{B}$ and $\mathrm{T}$ cells, macrophages and neutrophils (Elgazar-Carmon et al. 2008, Nishimura et al. 2009, Winer et al. 2011, Cawthorn et al. 2012, Talukdar et al. 2012). Adipocytes and immune cells produce a large number of bioactive substances (hormones, cytokines, ROS), collectively termed adipokines. These molecules influence the response of nearby or remote organs/ tissues including adipose tissue itself, heart, blood vessels, kidneys, skeletal muscle and liver, through autocrine, paracrine and/or endocrine mechanisms, with resulting effects on energy metabolism, systemic insulin sensitivity, glucose metabolism, immune response and vascular homeostasis (Trayhurn \& Beattie 2001, Kershaw \& Flier 2004, Hauner 2005, Tilg \& Moschen 2006, Eringa et al. 2007, Thalmann \& Meier 2007, Coelho et al. 2013) (Fig. 1).

Chronic over-nutrition triggers an inflammatory response initiated by WAT, leading to systemic and tissue specific low-grade inflammation and insulin resistance (Malnick \& Knobler 2006, Choe et al. 2016). In obese patients, adipose tissue mainly releases proinflammatory cytokines, among which are tumor necrosis factor alpha (TNF- $\alpha$ ), interleukin-6 (IL-6), monocyte chemotactic protein-1 (MCP-1) and ROS, which induce insulin resistance (Lumeng et al. 2007). Significant upregulation of leptin and downregulation of adiponectin gene expression are seen in mesenteric vWAT compared to scWAT and omental vWAT (Yang et al. 2008).

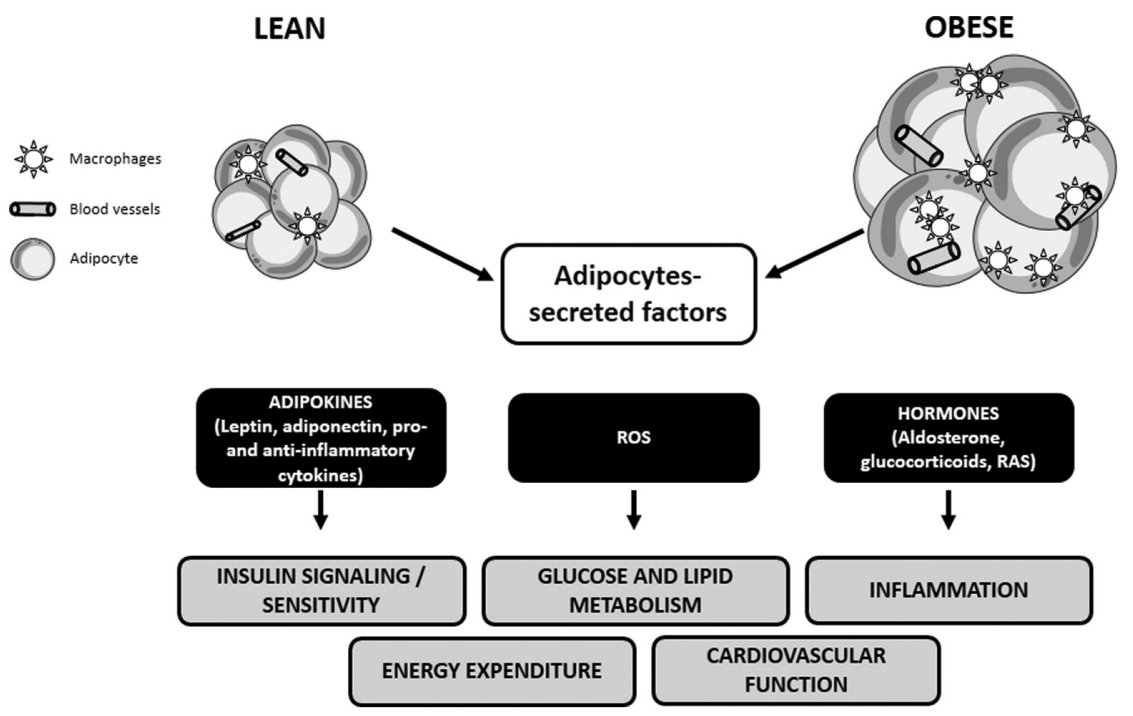

\section{Figure 1}

Endocrine function of adipose tissue. Adipose tissue secretes different factors including adipokines, reactive oxygen species and hormones that will affect a plethora of body physiological functions such as insulin signaling and sensitivity, glucose and lipid metabolism, energy expenditure, inflammation and cardiovascular function. In obesity, this function is altered leading to dysregulation of the production of these adipocytes-secreted factors, resulting in adipose tissue dysfunction and adverse effects on other tissues (cardiovascular, liver, muscle). RAS, renin angiotensin system; ROS, reactive oxygen species. http://joe.endocrinology-journals.org https://doi.org/10.1530/JOE-18-0163
() 2018 Society for Endocrinology Published by Bioscientifica Ltd.
Printed in Great Britain 


\section{Renin-angiotensin-aldosterone system in adipose tissue}

The renin-angiotensin-aldosterone system (RAAS) is one of the most important biological systems implicated in $\mathrm{CV}$ and metabolic diseases. In obesity, RAAS overactivation occurs in different insulin-sensitive tissues, particularly in adipose tissue (Engeli et al. 2000, Goossens et al. 2003). For the past 20 years, we have extended our view of MR-mediated aldosterone effects beyond epithelial tissues, like the kidney and the colon, with the discovery that MR is also expressed in other cell types such as in cardiomyocytes (Pearce \& Funder 1987, Barnett \& Pritchett 1988), in endothelial and vascular smooth muscle cells (Funder et al. 1989, Lombès et al. 1992) and in adipocytes (Rondinone et al. 1993, Nguyen Dinh Cat \& Jaisser 2012). However, for these cell types, target genes are not yet fully identified. Interestingly, adipocytes express all components of the RAAS (Thatcher et al. 2009). In particular, recent work has demonstrated that adipocytes secrete aldosterone and possess functional MRs (Briones et al. 2012). In adipocytes, it has been demonstrated that $\mathrm{MR}$ regulates adipokines secretion (Guo et al. 2008) and adipogenesis (Caprio et al. 2011) (Fig. 2). A recent in vivo study by Than and collaborators demonstrated that angiotensin II receptor type 2 (AT2R) activation in mice (treatment with compound C21) promotes WAT browning, raises body temperature and reduces WAT mass. In addition, the authors showed in cultured mouse and human white adipocyte induction of WAT browning through ERK1/2 MAP kinase, AKT and adenosine monophosphate kinase (AMPK) signaling pathways as well as increased UCP1 expression and that Ang II-mediated AT2R activation can enhance brown adipogenesis (Than et al. 2017). In comparison, Armani and coworkers reported that MR antagonism induced WAT browning in mice fed with high-fat diet, as evidenced by the increase in brown adipocytes markers gene expression and upregulation of Ucp1 levels. This may involve a direct regulation of adipocyte autophagy processes by MR (Armani et al. 2014). Hence, one can speculate that AT2R activation and MR blockade are part of a signaling pathway leading to WAT browning. In the studies by Than, it would have been interesting to determine whether there was a reduction in the autophagy process in adipocytes from C21-treated mice. A review on the different roles of the adipose angiotensin receptors in the endocrine, metabolic, immune and vasoactive functions of the adipose tissue has been published and thus will not be detailed here (Kalupahana \& Moustaid-Moussa 2012).

An important point is that unlike epithelial tissues that express the 11-beta hydroxysteroid dehydrogenase 2 enzyme (11 $\beta$-HSD2), which inactivates cortisol and corticosterone and thus confers aldosterone selectivity to the MR, adipose tissue is lacking this enzyme (or expressing it at very low levels) and active glucocorticoids are therefore also capable of activating the MR. Since glucocorticoids circulate at 100- to 1000-fold higher concentrations than those of aldosterone, it is very likely that they are the main endogenous ligand of the MR in adipose tissue. Numerous studies have described the role of glucocorticoids in adipose tissue. This has been summarized by Lee et al. (2014).

The existence of functional MR in adipose tissue has brought it out of the shadow of the glucocorticoid receptor (GR), considered for a long time as the solely player mediating corticosteroid action in adipose tissue and has opened a new area of research.

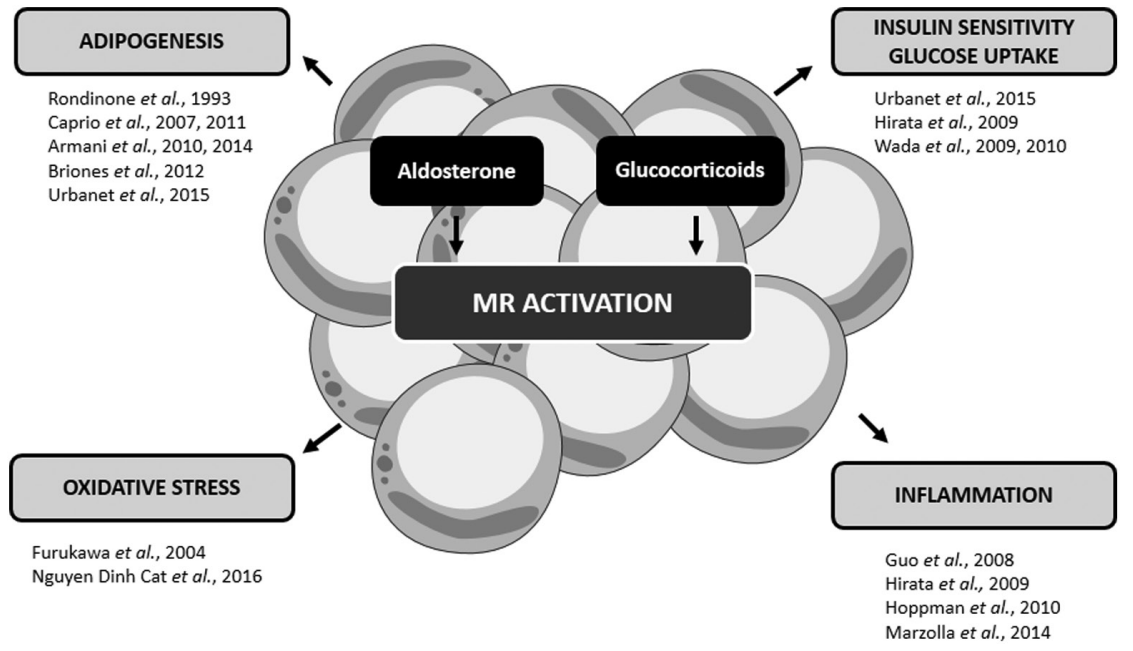

http://joe.endocrinology-journals.org https://doi.org/10.1530/JOE-18-0163
(C) 2018 Society for Endocrinology Published by Bioscientifica Ltd. Printed in Great Britain
Figure 2

Effects of MR activation in adipose tissue. A few group of researchers have centered their studies in the implication of MR activation in the pathogenesis of obesity. MR activation in adipose tissue stimulates adipogenesis, insulin sensitivity and glucose uptake, as well as can induce oxidative stress and inflammatory responses. MR, mineralocorticoid receptor. 
Different studies discussed the interplay between MR and GR in adipogenesis with contradictory results regarding identification of the main actor in this process. A study by Lee and Fried (2014), using RNA-interference knockdown of either GR or MR on primary cultures of human preadipocytes and adipocytes, led to the conclusion that GR mediates cortisol-induced adipogenesis (Lee \& Fried 2014). However, other studies showed a major role of the MR in adipogenesis in murine adipocytes cell lines, either 3T3-L1 or 3T3-F442A cells or in cell lines derived from adipocytes of GR- and MR-knockout mice (Caprio et al. 2007, Hoppmann et al. 2010). One of the possible explanation would be an intrinsic difference between species, but this issue is addressed as treatment with the MR antagonist drospirenone inhibited adipogenesis in human pre-adipocytes (Caprio et al. 2011). Taken altogether, these studies suggest that GR and MR could be implicated at different stages of differentiation and play a specific role depending on the fat depot or on the health status of the patient (obese vs lean) (Armani et al. 2014). Further studies are necessary to identify the precise roles of each corticosteroid receptors and to better understand the interactions between MR and GR in the regulation of adipogenesis.

\section{Aldosterone/MR in obesity and CMS}

Aldosterone has been linked with obesity and associated CMS since (a) it has been reported that patients with visceral obesity have higher levels of aldosterone (Rossi et al. 2008, Nagase \& Fujita 2009, Calhoun \& Sharma 2010, Vaidya et al. 2013); (b) the Framingham Offspring Study in which aldosterone was found to correlate positively with development of CMS and with a longitudinal change of its components (Ingelsson et al. 2007) and (c) it has been shown that excess of aldosterone exerts detrimental effects on glucose metabolism and insulin sensitivity and secretion. Indeed, aldosterone plasma levels have been reported to be associated with insulin resistance, characterized by a reduced ability of insulin to induce glucose uptake in adipose tissue and skeletal muscle in normotensive healthy subjects independent of traditional risk factors (Garg et al. 2010, Luther et al. 2011, Luther 2014).

Moreover, MR expression is increased in adipose tissue from obese patients as well as from obese $\mathrm{db} / \mathrm{db}$ mice (Hirata et al. 2012, Urbanet et al. 2015). Our group developed a conditional transgenic mouse model of MR overexpression specifically in adipocytes that displayed various components of the CMS: overweight, insulin resistance, hypercholesterolemia and hypertriglyceridemia (Urbanet et al. 2015), as well as vascular dysfunction (Nguyen Dinh Cat et al. 2016).

Interesting studies in obese mice have demonstrated beneficial effects of chronic treatment with MR antagonist on metabolic parameters with improvement in insulin sensitivity, glucose tolerance and adipose tissue inflammation (Guo et al. 2008, Hirata et al. 2009, Wada et al. 2010). However, the precise mechanisms by which MR activation leads to adipose tissue dysfunction and contribute to obesity and its associated CV complications are yet to be determined.

\section{Adipose tissue oxidative stress in obesity}

\section{ROS signaling in the adipose tissue}

ROS are oxygen-derived molecules produced in most cells, either as a result of endogenous (mitochondria aerobic metabolism, cytosolic enzymatic reactions) or exogenous (ionizing radiations, pollutants, drugs) sources (Finkel \& Holbrook 2000). Among ROS are the superoxide anion $\left(\mathrm{O}_{2}^{-}\right)$, the hydrogen peroxide $\left(\mathrm{H}_{2} \mathrm{O}_{2}\right)$, the hydroxyl anion $\left(\mathrm{OH}^{-}\right)$and the peroxynitrite anion $\left(\mathrm{OONO}^{-}\right)$. Superoxide is generated from molecular oxygen by addition of one unpaired electron. In aqueous solution, it behaves either as an oxidant agent, which is reduced to $\mathrm{H}_{2} \mathrm{O}_{2}$ spontaneously or by action of the superoxide dismutase (SOD), or as a reducing agent generating $\mathrm{ONOO}^{-}$by combination with nitric oxide (NO). $\mathrm{H}_{2} \mathrm{O}_{2}$, in turn, can be broken down by action of peroxidases or catalases into $\mathrm{H}_{2} \mathrm{O}$ and $\mathrm{O}_{2}$ or can be reduced to $\mathrm{OH}^{-}$in the presence of molecules containing $\mathrm{Fe}^{2+}$ (Schiffrin \& Touyz 2004) (Fig. 3A).

ROS are highly reactive molecules, which makes them essential second messengers, participating in many cell signaling pathways including proliferation, differentiation, immune response and apoptosis (Simon et al. 1998, Griendling et al. 2000). At physiological levels in adipose tissue, ROS participate in metabolic homeostasis as well as preadipocyte proliferation through an insulin-dependent pathway (Castro et al. 2016, Wagner et al. 2017) and in adipocyte differentiation through $\mathrm{H}_{2} \mathrm{O}_{2}$-induced cAMP response element-binding protein beta (C/EBP-beta) DNA-binding activity, along with C/EBP-beta phosphorylation (Lee et al. 2009, Tormos et al. 2011).

Mitochondria are major source of ROS. Complexes I and III of the mitochondrial electron transport chain 
A
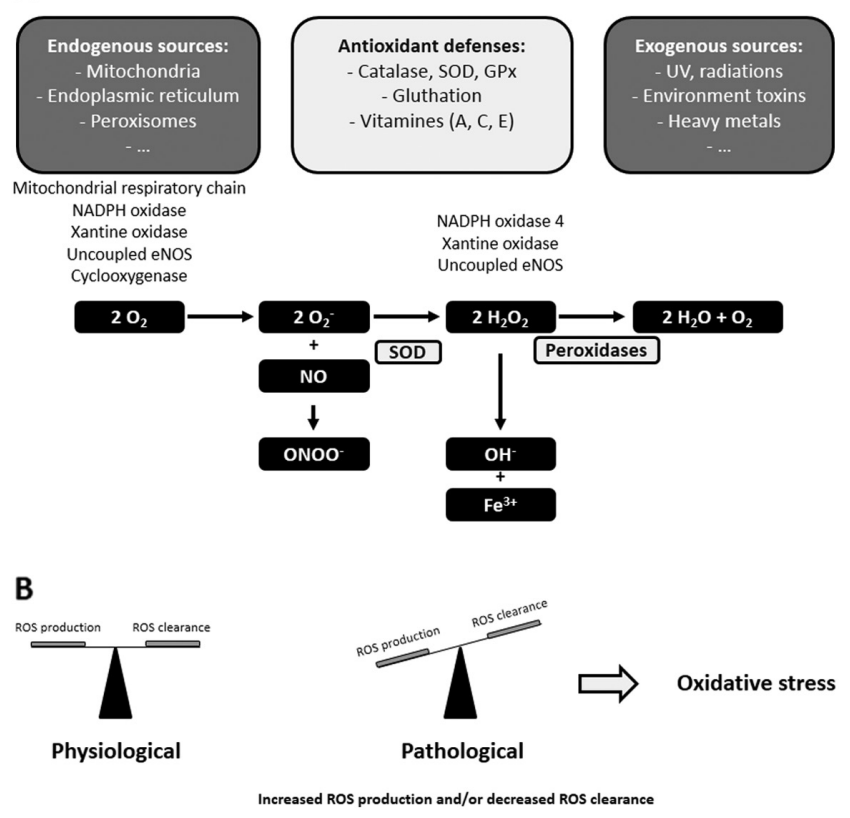

Figure 3

Sources of reactive oxygen species. (A) ROS production by different endogenous and exogenous sources is balanced with antioxidant defenses systems. Mitochondria are important for energy production through oxidative phosphorylation and are considered as one of the main sources of superoxide anion, predominantly produced by complexes I and III of the respiratory chain. ROS can also be produced by other enzymatic systems including NADPH oxidases. (B) Oxidative stress is defined as an imbalance between ROS production and ROS clearance by the antioxidant defense enzymes. eNOS, endothelial nitric oxide synthase; GPX, glutathione peroxidase; $\mathrm{H}_{2} \mathrm{O}_{2}$, hydrogen peroxide; $\mathrm{OH}^{-}$, hydroxyl anion; ONOO-, peroxynitrite; SOD, superoxide dismutase; UV, ultra-violets.

(ETC) are the main sources of superoxide anion, as they are responsible for $90-95 \%$ of its production under physiological conditions, by passing of electrons directly to oxygen (Korshunov et al. 1997, Miwa \& Brand 2003).

\section{Consequences of ROS imbalance in adipose tissue}

Oxidative stress is defined as an imbalance between ROS production and antioxidant capacity of defense systems. WAT is not regarded a mitochondria-rich tissue. Nonetheless, mitochondria and adequate mitochondrial function are essential for ATP synthesis, in order to support the energy requirements of adipocytes for processes like lipid metabolism (tricarboxylic acid cycle, $\beta$-oxidation) as well as for adipocyte differentiation and maturation. The relationship between obesity and ROS has been well established in the literature, with the presence of both systemic and organ-specific oxidative stress in adipose tissue, muscle and pancreas being recorded in obese patients (Furukawa et al. 2004). Consequently, long exposure to oxidative stress leads to DNA oxidative damage, triggering mitochondrial dysfunction that ultimately results in a vicious circle causing lipid accumulation and insulin resistance (Bournat \& Brown 2010). Imbalanced ROS levels lead to adipocyte dysfunction with impaired adipogenesis and insulin sensitivity, as well as adipocyte hypertrophy, which can lead to dysregulation of adipokines secretion (decreased adiponectin and increased leptin expression and secretion) and adipose tissue inflammation (Lee et al. 2009, Tormos et al. 2011, Yu et al. 2011, Wang et al. 2013, den Hartigh et al. 2017, Wagner et al. 2017) (Fig. 4). Obesity is associated with mitochondrial dysfunction and excessive production of mitochondrial ROS, leading to alteration of cellular components and to premature aging (Harman 1956, Halliwell 2006, Rong et al. 2007, Bjørndal et al. 2011, Kusminski \& Scherer 2012, Chattopadhyay et al. 2015, Castro et al. 2016).

\section{Remote effects of ROS in obesity}

In obesity, ROS accumulation in adipose tissue has harmful effects on the vasculature causing vascular dysfunction (endothelial dysfunction, vascular hypercontractility, stiffness) and chronic inflammation (Fernández-Sánchez et al. 2011, Manna \& Jain 2015). Indeed, perivascular adipose tissue from obese mice (New Zealand obese, high-fat diet and $\mathrm{db} / \mathrm{db}$ models) promotes endothelial dysfunction, vascular hypercontractility, as well as vascular insulin resistance and inflammation through redoxsensitive dependent mechanisms and pro-inflammatory cytokines induced by adipose-derived ROS (Marchesi et al. 2009, Ketonen et al. 2010, Fernández-Alfonso et al. 2013, Gil-Ortega et al. 2014, Nguyen Dinh Cat et al. 2018).

\section{The renin-angiotensin-aldosterone system and oxidative stress in obesity}

\section{MR activation and ROS production in obesity}

Among the enzymatic complexes that produce ROS, the family of NADPH oxidases (NOX) is one of the major sources of ROS and counts seven members: NOX1-5 and DUOX1 and 2, which differ in their tissue expression profile as well as in their mode of activation. All of them use NADPH as electron donor to produce $\mathrm{O}_{2}^{-}$, except NOX4 (Dikalov et al. 2008) and DUOXes, which produce $\mathrm{H}_{2} \mathrm{O}_{2}$ (Bedard \& Krause 2007).

The subunit p22phox is required for the formation of a functionally active NOX (except for NOX5). A study showed implication of the MR in the regulation of the 


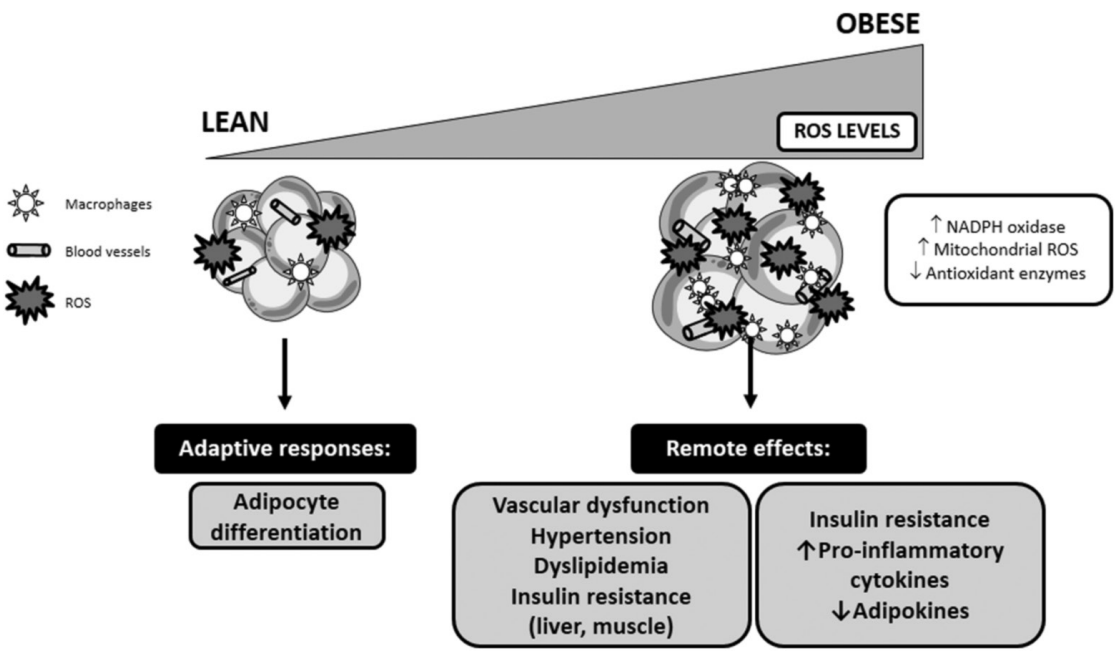

\section{Figure 4}

Consequences of ROS imbalance for adipose tissue function. Oxidative stress is originated in obesity increasing the risk for several metabolic dysfunction outcomes as well as adverse effects in other tissues (cardiovascular, liver, muscle). Physiological ROS levels are mandatory for a proper adipogenesis contributing to adipose tissue and overall organism homeostasis. If these levels are exacerbated the risk for developing obesity increases, leading to the disruption of several processes responsible for metabolism homeostasis. Indeed consequences of increased ROS levels in adipose tissue are insulin resistance (in fat, liver, muscle), inflammation, dyslipidemia and importantly vascular dysfunction. expression of p22phox in genetically and diet-induced obese mice. NOX subunit p22phox expression was significantly increased in the adipose tissue of obese mice compared to lean control, and treatment with the MR antagonist eplerenone normalized the expression (Hirata et al. 2009).

Oxidative stress does not necessarily result from overproduction of ROS and can be the consequence of a disruption in antioxidant defenses (Fig. 3B). Such antioxidant defenses include the SOD, which converts $\mathrm{O}_{2}$ - into $\mathrm{H}_{2} \mathrm{O}_{2}$, as well as catalase, thioredoxine reductase, glutathione peroxidases and peroxiredoxins, which are scavenging $\mathrm{H}_{2} \mathrm{O}_{2}$ into $\mathrm{H}_{2} \mathrm{O}$. There are three different SODs with specific cellular locations and cofactors: mitochondrial SOD (Mn-SOD or SOD2), cytosolic SOD (Cu/Zn-SOD or SOD1) and extracellular SOD (EC-SOD or SOD3) (Ursini et al. 1995, Faraci \& Didion 2004, Johnson \& Giulivi 2005, Wassmann et al. 2006). In obese $o b / o b$ and $d b / d b$ mice, expression of catalase, and Sod 1 were reduced compared with lean control mice and administration of eplerenone corrected this decrease (Hirata et al. 2009).

The Nrf2 transcription factor (or NFE2L2) regulates genes involved in antioxidant defenses, including hemooxygenase 1 (HO1), SOD3, glutathione peroxidase (GPX), thioredoxin and peroxiredoxin (Ma 2013). In the kidney, aldosterone has been shown to activate Nrf2 in the context of hypertension-induced oxidative DNA damage (Queisser et al. 2014). Contradicting results from animal studies show beneficial effects either of Nrf2 agonists administration in WT mice under highfat conditions or of Nrf2 knockout on metabolism and glucose homeostasis (Shin et al. 2009, Pi et al. 2010, Zhang et al. 2012, Choi et al. 2014, Schneider et al. 2016). Interestingly, mice with cell-specific deletion of $\mathrm{Nrf2}$, in adipocytes, hepatocytes (Chartoumpekis et al. 2018) or in myeloid cells (Collins et al. 2012), submitted to a highfat diet, do not recapitulate the protection against obesity obtained in the global deletion model. This suggests that the Nrf2 pathway may represent a promising target for treatment of obesity and T2D without clear identification of the exact molecular mechanisms.

\section{The renin-angiotensin-aldosterone system and regulators of mitochondrial function}

Strong evidence suggests that oxidative stress, in particular mitochondrial ROS, may mediate the effects of RAAS in obesity in multiple organs, contributing to mitochondrial dysfunction and insulin resistance (Ramalingam et al. 2017). In this review, we summarize the potential regulators of mitochondrial function and studies that indicate a putative interaction between RAAS activation and these regulators, although few data are available on adipose tissue (Fig. 5).

\section{Biogenesis, dynamics, mitophagy}

Mitochondrial biogenesis, mitophagy and dynamics are essential processes for quality control of mitochondria. In obese and diabetic patients, adipose tissue displays increased autophagy (Kosacka et al. 2015) and several studies have shown that inhibition of autophagyrelated pathways (TGF- $\beta$, Notch or Atg7) promotes beige adipocyte development and protects mice from dietinduced obesity and insulin resistance (Altshuler-Keylin \& Kajimura 2017, Taylor \& Gottlieb 2017). In skeletal muscle from Ang II-infused mice, mitochondrial integrity is impaired with reduced mitochondrial content, decreased autophagy, disorganized cristae structure and altered 


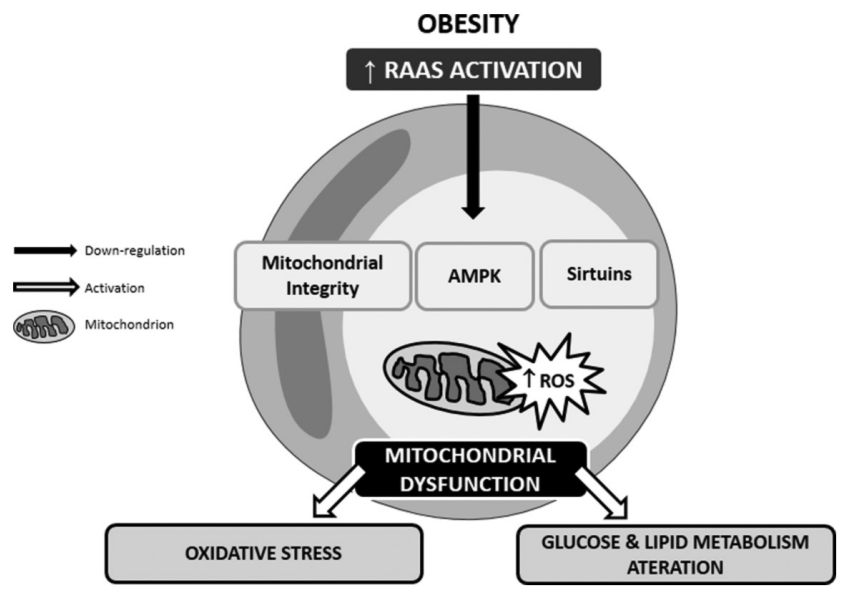

Figure 5

RAAS activation and mitochondrial dysfunction in obesity. Mitochondrial function is impaired in obesity. Some animal studies suggested close interactions between RAAS activation and mitochondrial dysfunction in obesity. Possible mechanisms underlying this complex RAAS-mitochondria relationship include dysregulation of mitochondrial biogenesis, mitophagy and dynamics, as well as downregulation of AMPK and sirtuins. Ultimately this results in increase in oxidative stress, altered glucose and lipids metabolism and insulin resistance. AMPK, AMPactivated protein kinase; ATP, adenosine triphosphate; RAAS, reninangiotensin-aldosterone system; ROS, reactive oxygen species.

dynamics (Mitsuishi et al. 2009, Silva et al. 2017). Thus, Ang II via stimulation of AT1R can cause mitochondrial morphological and functional abnormalities. This has been suggested to underlie the onset of skeletal muscle insulin resistance (Rogge 2009) as well as in other tissues including fat, liver, heart and vessels (Nisoli et al. 2007, Kim et al. 2008). In other cells, such as cardiomyocytes and vascular smooth muscle cells, mitochondrial ROS participate in the pathways triggered by RAAS activation via mitochondrial ATP-dependent potassium channels opening (Kimura et al. 2005, de Cavanagh et al. 2007, De Giusti et al. 2013). Moreover, RAAS inhibitors protect mitochondria against oxidative stress-induced damage (de Cavanagh et al. 2004).

Mitochondria are highly dynamic organelles organized in a complex network. Fission is the division of the mitochondrial tubular network into fragmented and isolated mitochondria, a process strongly connected to increased oxidative stress and mitophagy (removal of mitochondria). Fusion of mitochondria results in an enhanced tubular network and is associated with a reduction of oxidative stress. Therefore, alterations in the systems regulating mitochondrial dynamics are also major regulators of mitochondrial function, impacting mtDNA copy number. In the kidney from aldosterone-infused mice,
mtDNA copy number is diminished and associated with mitochondrial dysfunction (Zhu et al. 2011). Similar results were obtained in aldosterone- and-salttreated rats as well as in aldosterone-treated human cardiac fibroblasts (Ibarrola et al. 2018).

\section{Sirtuins, AMPK, oxidative stress and MR}

AMPK and sirtuins are major regulators of mitochondrial function and can thus influence mitochondrial oxidative stress (Ruderman et al. 2010). In vitro studies reported that inhibition of AMPK activity in 3T3-L1 adipocytes led to increase in both ROS production and lipolysis (Gauthier et al. 2008). Besides, acute oxidative stress induces AMPK activation in HEK-293 cells (Auciello et al. 2014). These elements suggest that reduced AMPK activity and increased oxidative stress could be causal factors for each other (Xu et al. 2012).

Similarly, sirtuin expression can be influenced by oxidative stress: indeed, severe or chronic oxidative stress induces sirtuin degradation by the proteasome while mild oxidative stress causes a compensatory overexpression (Santos et al. 2016). Global knockout of the Sirt1 gene in adult mice prevents resveratrol-induced AMPK activation, indicating that SIRT1 induces AMPK activation (Price et al. 2012).

\section{AMPK pathway}

The AMP/ATP cellular ratio is a gauge of the cell energy status. When this ratio increases, AMPK is activated, switching on glucose transport and catabolic pathways as lipolysis to generate ATP and inhibiting fatty acid synthesis and oxidation (Hardie 2003). AMPK has a protective role against obesity and adipose tissue unhealthy expansion. Indeed, high-fat diet-fed AMPK $\alpha 2$-knockout mice exhibit increased fat mass, resulting from adipocyte hypertrophy rather than hyperplasia (Villena et al. 2004). In obese insulin-resistant patients, AMPK activity in adipose tissue is decreased (Xu et al. 2012).

Crosstalk between AMPK and RAAS has been demonstrated in kidney and in cardiomyocytes (Stuck et al. 2008, Hernández et al. 2014, Yang et al. 2016). One can speculate that these interactions might also occur in adipose tissue. Recently, it has been shown that AMPK activation by metformin treatment suppresses aldosterone-induced fibrosis in heart (Mummidi et al. 2016) and adipose tissue remodeling, as well as insulin resistance in obesity (Luo et al. 2016). An interesting study recently provided in vitro and in vivo evidence that Ang II 
via AT2R induces browning and brown adipogenesis through, in part, AMPK signaling pathways (Than et al. 2017). Ongoing research investigates the contribution of AMPK in aldosterone secretion by adipocytes and whether AMPK activators drugs would prevent Ang II and aldosterone-induced pro-inflammatory effects in human and mouse adipocytes MR activation (White et al. 2015).

\section{Sirtuins and RAAS}

Research on caloric restriction has led to the discovery of sirtuins (silent information regulators (SIRT)), redoxsensitive NAD+-dependent deacetylases/deacylases regulating various cellular functions, including glucose and lipid metabolism as well as adipocytes differentiation. There are seven mammalian SIRTs. Their respective roles in energy metabolism have been reviewed by Li \& Kazgan (2011). Studies have brought evidence that SIRT1 and SIRT3 can regulate the activity of several mitochondrial enzymes through deacetylation of PGC1-alpha or the forkhead protein FOXO1 or activation of complex I, resulting in control of ATP production (Nogueiras et al. 2012). Recent studies demonstrated beneficial effects of resveratrol (sirtuins activator) on glucose metabolism and insulin sensitivity, closely associated with AMPK activation (Civitarese et al. 2007, Um et al. 2010, Timmers et al. 2011). In rodent studies submitted to high-fat diet, treatment with resveratrol protected the mice against obesity by increasing energy expenditure (Kim et al. 2011, Cho et al. 2012), improving mitochondrial activity of brown adipocytes (Lagouge et al. 2006, Ku \& Lee 2016) and inducing browning of WAT (Wang et al. 2015, Arias et al. 2017). RAAS components and sirtuins expression levels in adipose tissue are influenced by diet composition. Indeed a lipid-rich diet induces upregulation of ACE and downregulation of Ace2 and Sirt4 in mice (de Pinho et al. 2013).

Angiotensin-converting enzyme/Ang II/AT1R activation is counterbalanced by ACE2/angiotensin-(1-7)/ Mas axis that has been shown to interact with sirtuins in adipose tissue. Indeed, administration of Ang-(1-7) or resveratrol in high-fat diet-induced obese mice improved glucose and lipid metabolic parameters in WAT by modulating Sirt1, Ace1 and Ace2 expressions, respectively (Oliveira Andrade et al. 2014). Other studies, not necessarily in the context of obesity, showed inhibitory effect of resveratrol on AT1R expression through SIRT1 activation in CV tissues (Miyazaki et al. 2008, Kim et al. 2018).

\section{Clinical perspectives and potential therapeutic applications of selective MR antagonists}

The different options for the management of obesity and its complications include lifestyle changes through progressive increase of physical activity and adapted diets; medical treatments and bariatric surgery in the most severe cases.

Among the different drugs available for obesity complications treatment, biguanides and thiazolidinediones (TZDs) have a mitochondria-targeted mechanism, through inhibition of the ETC complex I. Moreover, it has recently been established that metformin treatment in diabetic mice protected mitochondrial integrity by inhibiting dynamin-related protein 1 (DRP1) activation through an AMPK-dependent mechanism (Li et al. 2016), while TZDs inhibit mitochondrial pyruvate carrier activity (Colca et al. 2014). However, frequent side effects are reported, including kidney and liver complications as well as weight gain. As there seems to be a crosstalk between RAAS and AMPK, MR antagonists could represent an alternative way of raising AMPK levels.

RAAS activation induces oxidative stress and dietary anti-oxidants (zinc, $\alpha$-lipoic acid, vitamin $\mathrm{C}$ and $\mathrm{E}$, lycopene) are a side strategy for management of obesity. With only few studies being available on the exact efficacy of this supplementation, as most studies are observational and there are almost no interventional studies, the causality link is difficult to establish (Abdali et al. 2015). Inhibition of the MR could be a more efficient way of tackling oxidative stress in obesity.

An additional strategy to treat obesity is to increase BAT activity and/or mass to promote energy consumption via non-shivering thermogenesis. In 2015, Liu et al. (2015) showed that transplantation of BAT from control mice in ob/ob mice reduces weight gain, decreases adipose tissue hypertrophy, hepatic steatosis and improves insulin sensitivity and adiponectin plasma levels. Moreover, the activity of the endogenous BAT was increased by the presence of the transplanted BAT. However, transplantation would be difficult in human as the BAT is rather diffused and would make collection from a donor in a sufficient quantity quite challenging. Luckily, alternative ways of activating the endogenous BAT are available. Among drugs capable of inducing such browning is CL 316243, an agonist of the $\beta 3$ adrenergic receptor, which not only promotes BAT activity but also protects against WAT 
hyperplasia in the early stages of obesity (Wankhade et al. 2016). The TZD-derived partial PPAR $\gamma$ agonist GQ-16 decreased weight gain in spite of higher energy intake, reduced fat mass and liver TG content and increased morphological and molecular markers of BAT activation in male high-fat diet-fed Swiss mice (Coelho et al. 2016). Another drug, the anti-cancer drug Gleevec improved insulin sensitivity, decreased inflammation in adipose tissues and promoted browning of WAT via PPAR $\gamma$ phosphorylation inhibition at $\operatorname{Ser}^{273}$ (Choi et al. 2016). However, CL 316243 and GQ-16 are not commercialized as drugs and Gleevec causes serious side effects and impacts quality of life. MR antagonists have the advantage of being already used in clinic and with known and manageable side effects.

\section{Conclusion}

Far from being a simple reservoir for nutrient storage, adipose tissue is now recognized as one of the central players in the integration and control of metabolic homeostasis and energy balance. Among other regulatory factors, adipose tissue is a target for steroid hormones, since adipocytes express GR, MR, but also androgen and estrogen receptors. For a long time, no one was suspecting a possible role of MR activation in adipose tissue. New and unexpected roles for adipose MRs have been revealed by recent studies demonstrating its direct implication in the regulation of adipocyte differentiation and expansion, proinflammatory capacity, insulin signaling and adipokines secretion. In addition, numerous research studies have confirmed that, in obesity, MR is over-activated and contributes to low-grade inflammation, insulin resistance and CV injury. Moreover, this review has summarized evidence that obesity is often associated with oxidative stress and mitochondrial dysfunction. Thus, further studies are needed to understand the exact mechanisms by which MR over-activation in obesity induces adipose tissue dysfunction. Figure 6 is representing the hypothetical crosstalk between MR activation, oxidative stress and mitochondrial function. Indeed, the close link between the mechanisms controlling oxidative stress and mitochondrial function, allowing to preserve adipose tissue homeostasis, have placed the mineralocorticoid system as an attractive and central candidate in the development of obesity and its associated metabolic complications.

Even if studies in animal models of obesity showed a marked improvement of overall adipose tissue function

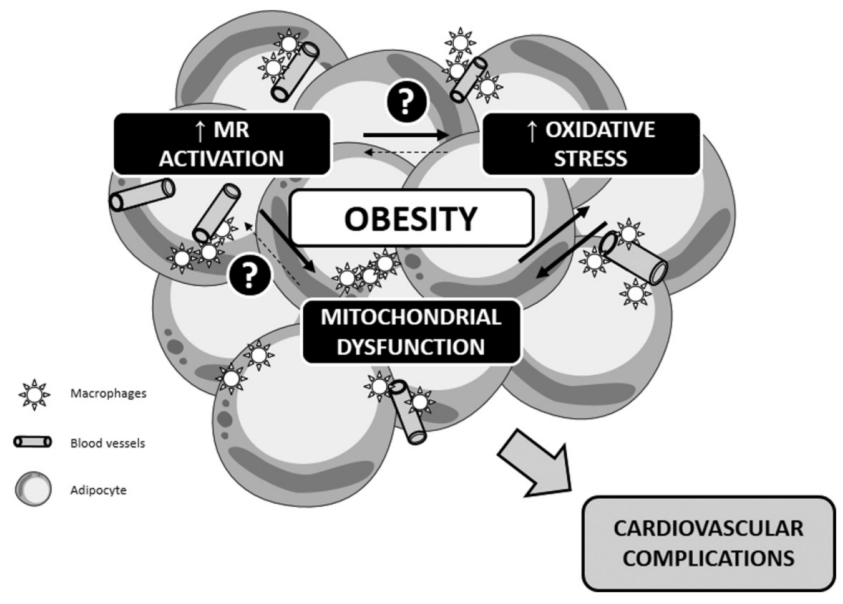

Figure 6

Hypothetical scheme representing the relationship between MR activation, oxidative stress and mitochondrial dysfunction in obesity. Obesity is often associated with increased oxidative stress and mitochondrial dysfunction. Further studies are necessary to clarify the crosstalk between MR activation and these processes and to understand the contribution of adipose MR activation in the cardiovascular complications associated with obesity.

after treatment with MR blockers, to date, no clinical trials in humans has addressed the impact of MR antagonism on body fat mass and metabolic function as a primary end-point. Nevertheless, indirect evidence have emerged from clinical studies of drospirenone, a potent synthetic anti-mineralocorticoid with progestogenic and moderate anti-androgenic properties, combined with estrogens for contraception and hormone replacement therapy (Palacios et al. 2006). Of particular interest, drospirenone had positive impact on CMS components such as blood pressure and fat mass gain (Tankó \& Christiansen 2005, White et al. 2005, 2006, Preston et al. 2007). Based on these observations, Caprio and collaborators demonstrated a potent MR-dependent antiadipogenic effect of drospirenone on human primary pre-adipocytes from different fat depots, providing some mechanistic insights for the observed favorable effects of drospirenone on body weight and metabolism (Caprio et al. 2011). Clinical studies using MR antagonists alone or in combination with actual treatments in selected cohorts of obese patients should allow validation of beneficial effects of MR blockade on metabolic and CV parameters.

\section{Declaration of interest}

The authors declare that there is no conflict of interest that could be perceived as prejudicing the impartiality of this review. 
Bournat JC \& Brown CW 2010 Mitochondrial dysfunction in obesity. Current Opinion in Endocrinology, Diabetes, and Obesity 17 446-452. (https://doi.org/10.1097/MED.0b013e32833c3026)

This work was made possible with funding from CARMMA Avenir investment program (ANR-15-RHUS-0003), the Fondation de France (2014-00047968), and the European COST-ADMIRE 1301 network. M F P is supported by funding from the Wenner-Gren Foundations, the Magnus Bergvall Foundation and the Åke Wiberg Foundation.

\section{Acknowledgements}

The authors would like to thank Dr Maria Dulak-Lis and Dr Sofia Tsiropoulou for critical appraisal and editing of the manuscript.

\section{References}

Abdali D, Samson SE \& Grover AK 2015 How effective are antioxidant supplements in obesity and diabetes? Medical Principles and Practice $\mathbf{2 4}$ 201-215. (https://doi.org/10.1159/000375305)

Alberti KGMM, Eckel RH, Grundy SM, Zimmet PZ, Cleeman JI, Donato KA, Fruchart J-C, James WPT, Loria CM, Smith SC, et al. 2009 Harmonizing the metabolic syndrome: a joint interim statement of the International Diabetes Federation Task Force on Epidemiology and Prevention; National Heart, Lung, and Blood Institute; American Heart Association; World Heart Federation; International Atherosclerosis Society; and International Association for the Study of Obesity. Circulation 120 1640-1645. (https://doi.org/10.1161/ CIRCULATIONAHA.109.192644)

Altshuler-Keylin S \& Kajimura S 2017 Mitochondrial homeostasis in adipose tissue remodeling. Science Signaling 10 eaai9248. (https://doi. org/10.1126/scisignal.aai9248)

Arias N, Picó C, Teresa Macarulla M, Oliver P, Miranda J, Palou A \& Portillo MP 2017 A combination of resveratrol and quercetin induces browning in white adipose tissue of rats fed an obesogenic diet. Obesity 25 111-121. (https://doi.org/10.1002/oby.21706)

Armani A, Mammi C, Marzolla V, Calanchini M, Antelmi A, Rosano GMC, Fabbri A \& Caprio M 2010 Cellular models for understanding adipogenesis, adipose dysfunction, and obesity. Journal of Cellular Biochemistry 110 564-572. (https://doi.org/10.1002/ jcb.22598)

Armani A, Cinti F, Marzolla V, Morgan J, Cranston GA, Antelmi A, Carpinelli G, Canese R, Pagotto U, Quarta C, et al. 2014 Mineralocorticoid receptor antagonism induces browning of white adipose tissue through impairment of autophagy and prevents adipocyte dysfunction in high-fat-diet-fed mice. FASEB Journal $\mathbf{2 8}$ 3745-3757. (https://doi.org/10.1096/fj.13-245415)

Auciello FR, Ross FA, Ikematsu N \& Hardie DG 2014 Oxidative stress activates AMPK in cultured cells primarily by increasing cellular AMP and/or ADP. FEBS Letters 588 3361-3366. (https://doi.org/10.1016/j. febslet.2014.07.025)

Barnett C \& Pritchett E 1988 Detection of corticosteroid type I binding sites in heart. Molecular and Cellular Endocrinology 56 191-198. (https://doi.org/10.1016/0303-7207(88)90060-3)

Bartelt A \& Heeren J 2014 Adipose tissue browning and metabolic health. Nature Reviews Endocrinology 10 24-36. (https://doi.org/10.1038/ nrendo.2013.204)

Bedard K \& Krause KH 2007 The NOX family of ROS-generating NADPH oxidases: physiology and pathophysiology. Physiological Reviews $\mathbf{8 7}$ 245-313. (https://doi.org/10.1152/physrev.00044.2005)

Bjørndal B, Burri L, Staalesen V, Skorve J \& Berge RK 2011 Different adipose depots: their role in the development of metabolic syndrome and mitochondrial response to hypolipidemic agents. Journal of Obesity 2011 490650. (https://doi.org/10.1155/2011/490650)
Briones AM, Nguyen Dinh Cat A, Callera GE, Yogi A, Burger D, He Y, Corrêa JW, Gagnon AM, Gomez-Sanchez CE, Gomez-Sanchez EP, et al. 2012 Adipocytes produce aldosterone through calcineurin-dependent signaling pathways: implications in diabetes mellitus-associated obesity and vascular dysfunction. Hypertension 59 1069-1078. (https://doi.org/10.1161/HYPERTENSIONAHA.111.190223)

Calhoun DA \& Sharma K 2010 The role of aldosteronism in causing obesity-related cardiovascular risk. Cardiology Clinics 28 517-527. (https://doi.org/10.1016/j.ccl.2010.04.001)

Caprio M, Fève B, Claës A, Viengchareun S, Lombès M \& Zennaro M-C 2007 Pivotal role of the mineralocorticoid receptor in corticosteroidinduced adipogenesis. FASEB Journal 21 2185-2194. (https://doi. org/10.1096/fj.06-7970com)

Caprio M, Antelmi A, Chetrite G, Muscat A, Mammi C, Marzolla V, Fabbri A, Zennaro M-C \& Fève B 2011 Antiadipogenic effects of the mineralocorticoid receptor antagonist drospirenone: potential implications for the treatment of metabolic syndrome. Endocrinology 152 113-125. (https://doi.org/10.1210/en.2010-0674)

Castro JP, Grune T \& Speckmann B 2016 The two faces of reactive oxygen species (ROS) in adipocyte function and dysfunction. Biological Chemistry 397 709-724. (https://doi.org/10.1515/hsz-2015-0305)

Cawthorn WP, Scheller EL \& MacDougald OA 2012 Adipose tissue stem cells: the great WAT hope. Trends in Endocrinology and Metabolism 23 270-277. (https://doi.org/10.1016/j.tem.2012.01.003)

Chartoumpekis DV, Palliyaguru DL, Wakabayashi N, Fazzari M, Khoo NK, Schopfer FJ, Sipula I, Yagishita Y, Michalopoulos GK, O'Doherty RM, et al. 2018 Nrf2 deletion from adipocytes, but not hepatocytes, potentiates systemic metabolic dysfunction after long-term highfat diet-induced obesity in mice. American Journal of Physiology: Endocrinology and Metabolism [epub]. (https://doi.org/10.1152/ ajpendo.00311.2017)

Chattopadhyay M, Khemka VK, Chatterjee G, Ganguly A, Mukhopadhyay S \& Chakrabarti S 2015 Enhanced ROS production and oxidative damage in subcutaneous white adipose tissue mitochondria in obese and type 2 diabetes subjects. Molecular and Cellular Biochemistry 399 95-103. (https://doi.org/10.1007/s11010014-2236-7)

Cho S-J, Jung UJ \& Choi M-S 2012 Differential effects of low-dose resveratrol on adiposity and hepatic steatosis in diet-induced obese mice. British Journal of Nutrition 108 2166-2175. (https://doi. org/10.1017/S0007114512000347)

Choe SS, Huh JY, Hwang IJ, Kim JI \& Kim JB 2016 Adipose tissue remodeling: its role in energy metabolism and metabolic disorders. Frontiers in Endocrinology 7 30. (https://doi.org/10.3389/ fendo.2016.00030)

Choi K-M, Lee Y-S, Kim W, Kim SJ, Shin K-O, Yu J-Y, Lee MK, Lee Y-M, Hong JT, Yun Y-P, et al. 2014 Sulforaphane attenuates obesity by inhibiting adipogenesis and activating the AMPK pathway in obese mice. Journal of Nutritional Biochemistry 25 201-207. (https://doi. org/10.1016/j.jnutbio.2013.10.007)

Choi S-S, Kim E-S, Jung J-E, Marciano DP, Jo A, Koo JY, Choi SY, Yang YR, Jang H-J, Kim E-K, et al. 2016 PPAR $\gamma$ antagonist gleevec improves insulin sensitivity and promotes the browning of white adipose tissue. Diabetes 65 829-839. (https://doi.org/10.2337/db15-1382)

Civitarese AE, Carling S, Heilbronn LK, Hulver MH, Ukropcova B, Deutsch WA, Smith SR, Ravussin E \& CALERIE Pennington Team 2007 Calorie restriction increases muscle mitochondrial biogenesis in healthy humans. PLoS Medicine 4 e76. (https://doi.org/10.1371/ journal.pmed.0040076)

Coelho M, Oliveira T \& Fernandes R 2013 Biochemistry of adipose tissue: an endocrine organ. Archives of Medical Science 9 191-200. (https:// doi.org/10.5114/aoms.2013.33181) 
Coelho MS, de Lima CL, Royer C, Silva JB, Oliveira FCB, Christ CG, Pereira SA, Bao SN, Lima MCA, Pitta MGR, et al. 2016 GQ-16, a TZD-derived partial PPAR $\gamma$ agonist, induces the expression of thermogenesis-related genes in brown fat and visceral white fat and decreases visceral adiposity in obese and hyperglycemic mice. PLoS ONE 11 e0154310. (https://doi.org/10.1371/journal.pone.0154310)

Colca JR, McDonald WG \& Kletzien RF 2014 Mitochondrial target of thiazolidinediones. Diabetes, Obesity and Metabolism 16 1048-1054. (https://doi.org/10.1111/dom.12308)

Collins AR, Gupte AA, Ji R, Ramirez MR, Minze LJ, Liu JZ, Arredondo M, Ren Y, Deng T, Wang J, et al. 2012 Myeloid deletion of nuclear factor erythroid 2-related factor 2 increases atherosclerosis and liver injury. Arteriosclerosis, Thrombosis, and Vascular Biology 32 2839-2846. (https://doi.org/10.1161/ATVBAHA.112.300345)

Cypess AM, Weiner LS, Roberts-Toler C, Franquet Elía E, Kessler SH, Kahn PA, English J, Chatman K, Trauger SA, Doria A, et al. 2015 Activation of human brown adipose tissue by a $\beta 3$-adrenergic receptor agonist. Cell Metabolism 21 33-38. (https://doi.org/10.1016/j. cmet.2014.12.009)

de Cavanagh EMV, Piotrkowski B \& Fraga CG 2004 Concerted action of the renin-angiotensin system, mitochondria, and antioxidant defenses in aging. Molecular Aspects of Medicine 25 27-36. (https://doi. org/10.1016/j.mam.2004.02.006)

de Cavanagh EMV, Inserra F, Ferder M \& Ferder L 2007 From mitochondria to disease: role of the renin-angiotensin system. American Journal of Nephrology 27 545-553. (https://doi. org/10.1159/000107757)

De Giusti VC, Caldiz CI, Ennis IL, Pérez NG, Cingolani HE \& Aiello EA 2013 Mitochondrial reactive oxygen species (ROS) as signaling molecules of intracellular pathways triggered by the cardiac reninangiotensin II-aldosterone system (RAAS). Frontiers in Physiology 4 126. (https://doi.org/10.3389/fphys.2013.00126)

de Pinho L, Andrade JMO, Paraíso A, Filho ABM, Feltenberger JD, Guimarães ALS, de Paula AMB, Caldeira AP, de Carvalho Botelho AC, Campagnole-Santos MJ, et al. 2013 Diet composition modulates expression of sirtuins and renin-angiotensin system components in adipose tissue. Obesity 21 1830-1835. (https://doi.org/10.1002/ oby.20305)

den Hartigh LJ, Omer M, Goodspeed L, Wang S, Wietecha T, O'Brien KD \& Han CY 2017 Adipocyte-specific deficiency of NADPH oxidase 4 delays the onset of insulin resistance and attenuates adipose tissue inflammation in obesity. Arteriosclerosis, Thrombosis, and Vascular Biology 37 466-475. (https://doi.org/10.1161/ ATVBAHA.116.308749)

Dikalov SI, Dikalova AE, Bikineyeva AT, Schmidt HH, Harrison DG \& Griendling KK 2008 Distinct roles of Nox1 and Nox4 in basal and angiotensin II-stimulated superoxide and hydrogen peroxide production. Free Radical Biology and Medicine 45 1340-1351. (https:// doi.org/10.1016/j.freeradbiomed.2008.08.013)

Elgazar-Carmon V, Rudich A, Hadad N \& Levy R 2008 Neutrophils transiently infiltrate intra-abdominal fat early in the course of high-fat feeding. Journal of Lipid Research 49 1894-1903. (https://doi. org/10.1194/jlr.M800132-JLR200)

Engeli S, Negrel R \& Sharma AM 2000 Physiology and pathophysiology of the adipose tissue renin-angiotensin system. Hypertension $\mathbf{3 5}$ 1270-1277. (https://doi.org/10.1161/01.HYP.35.6.1270)

Eringa EC, Bakker W, Smulders YM, Serné EH, Yudkin JS \& Stehouwer CDA 2007 Regulation of vascular function and insulin sensitivity by adipose tissue: focus on perivascular adipose tissue. Microcirculation 14 389-402. (https://doi. org/10.1080/10739680701303584)

Even SEL, Dulak-Lis MG, Touyz RM \& Nguyen Dinh Cat A 2014 Crosstalk between adipose tissue and blood vessels in cardiometabolic syndrome: implication of steroid hormone receptors (MR/GR). Hormone Molecular Biology and Clinical Investigation 19 89-101. (https://doi.org/10.1515/hmbci-2014-0013)
Fallo F, Veglio F, Bertello C, Sonino N, Della Mea P, Ermani M, Rabbia F, Federspil G \& Mulatero P 2006 Prevalence and characteristics of the metabolic syndrome in primary aldosteronism. Journal of Clinical Endocrinology and Metabolism 91 454-459. (https://doi.org/10.1210/ jc.2005-1733)

Faraci FM \& Didion SP 2004 Vascular protection: superoxide dismutase isoforms in the vessel wall. Arteriosclerosis, Thrombosis, and Vascular Biology 24 1367-1373. (https://doi.org/10.1161/01. ATV.0000133604.20182.cf)

Feldmann HM, Golozoubova V, Cannon B \& Nedergaard J 2009 UCP1 ablation induces obesity and abolishes diet-induced thermogenesis in mice exempt from thermal stress by living at thermoneutrality. Cell Metabolism 9 203-209. (https://doi.org/10.1016/j.cmet.2008.12.014)

Feliciano Pereira P, Eloiza Priore S \& Bressan J 2014 Aldosterone: a cardiometabolic risk hormone? Nutricion Hospitalaria 30 1191-1202. (https://doi.org/10.3305/nh.2014.30.6.7725)

Fernández-Alfonso MS, Gil-Ortega M, García-Prieto CF, Aranguez I, RuizGayo M \& Somoza B 2013 Mechanisms of perivascular adipose tissue dysfunction in obesity. International Journal of Endocrinology $\mathbf{2 0 1 3}$ 402053. (https://doi.org/10.1155/2013/402053)

Fernández-Sánchez A, Madrigal-Santillán E, Bautista M, Esquivel-Soto J, Morales-González A, Esquivel-Chirino C, Durante-Montiel I, SánchezRivera G, Valadez-Vega C \& Morales-González JA 2011 Inflammation, oxidative stress, and obesity. International Journal of Molecular Sciences 12 3117-3132. (https://doi.org/10.3390/ijms12053117)

Finkel T \& Holbrook NJ 2000 Oxidants, oxidative stress and the biology of ageing. Nature $\mathbf{4 0 8}$ 239-247. (https://doi.org/10.1038/35041687)

Funder JW, Pearce PT, Smith R \& Campbell J 1989 Vascular type I aldosterone binding sites are physiological mineralocorticoid receptors. Endocrinology 125 2224-2226. (https://doi.org/10.1210/ endo-125-4-2224)

Furukawa S, Fujita T, Shimabukuro M, Iwaki M, Yamada Y, Nakajima Y, Nakayama O, Makishima M, Matsuda M \& Shimomura I 2004 Increased oxidative stress in obesity and its impact on metabolic syndrome. Journal of Clinical Investigation 114 1752-1761. (https:// doi.org/10.1172/JCI200421625)

Garg R, Hurwitz S, Williams GH, Hopkins PN \& Adler GK 2010 Aldosterone production and insulin resistance in healthy adults. Journal of Clinical Endocrinology and Metabolism 95 1986-1990. (https://doi.org/10.1210/jc.2009-2521)

Gauthier M-S, Miyoshi H, Souza SC, Cacicedo JM, Saha AK, Greenberg AS \& Ruderman NB 2008 AMP-activated protein kinase is activated as a consequence of lipolysis in the adipocyte potential mechanism and physiological relevance. Journal of Biological Chemistry $\mathbf{2 8 3}$ 16514-16524. (https://doi.org/10.1074/jbc.M708177200)

Gesta S, Blüher M, Yamamoto Y, Norris AW, Berndt J, Kralisch S, Boucher J, Lewis C \& Kahn CR 2006 Evidence for a role of developmental genes in the origin of obesity and body fat distribution. PNAS 103 6676-6681. (https://doi.org/10.1073/ pnas.0601752103)

Gil-Ortega M, Condezo-Hoyos L, García-Prieto CF, Arribas SM, González MC, Aranguez I, Ruiz-Gayo M, Somoza B \& FernándezAlfonso MS 2014 Imbalance between pro and anti-oxidant mechanisms in perivascular adipose tissue aggravates long-term highfat diet-derived endothelial dysfunction. PLOS ONE 9 e95312. (https:// doi.org/10.1371/journal.pone.0095312)

Goodfriend TL, Kelley DE, Goodpaster BH \& Winters SJ 1999 Visceral obesity and insulin resistance are associated with plasma aldosterone levels in women. Obesity Research 7 355-362. (https://doi. org/10.1002/j.1550-8528.1999.tb00418.x)

Goossens GH, Blaak EE \& van Baak MA 2003 Possible involvement of the adipose tissue renin-angiotensin system in the pathophysiology of obesity and obesity-related disorders. Obesity Reviews 4 43-55. (https://doi.org/10.1046/j.1467-789X.2003.00091.x)

Griendling KK, Sorescu D, Lassegue B \& Ushio-Fukai M 2000 Modulation of protein kinase activity and gene expression by reactive oxygen 
species and their role in vascular physiology and pathophysiology. Arteriosclerosis, Thrombosis, and Vascular Biology 20 2175-2183. (https://doi.org/10.1161/01.ATV.20.10.2175)

Guo C, Ricchiuti V, Lian BQ, Yao TM, Coutinho P, Romero JR, Li J, Williams GH \& Adler GK 2008 Mineralocorticoid receptor blockade reverses obesity-related changes in expression of adiponectin, peroxisome proliferator-activated receptor-gamma, and proinflammatory adipokines. Circulation 117 2253-2261. (https://doi. org/10.1161/CIRCULATIONAHA.107.748640)

Halliwell B 2006 Reactive species and antioxidants. Redox biology is a fundamental theme of aerobic life. Plant Physiology 141 312-322. (https://doi.org/10.1104/pp.106.077073)

Hardie DG 2003 Minireview: the AMP-activated protein kinase cascade: the key sensor of cellular energy status. Endocrinology 144 5179-5183. (https://doi.org/10.1210/en.2003-0982)

Harman D 1956 Aging: a theory based on free radical and radiation chemistry. Journal of Gerontology 11 298-300. (https://doi. org/10.1093/geronj/11.3.298)

Hauner H 2005 Secretory factors from human adipose tissue and their functional role. Proceedings of the Nutrition Society 64 163-169. (https://doi.org/10.1079/PNS2005428)

Hernández JS, Barreto-Torres G, Kuznetsov AV, Khuchua Z \& Javadov S 2014 Crosstalk between AMPK activation and angiotensin II-induced hypertrophy in cardiomyocytes: the role of mitochondria. Journal of Cellular and Molecular Medicine 18 709-720. (https://doi.org/10.1111/ jcmm.12220)

Hirata A, Maeda N, Hiuge A, Hibuse T, Fujita K, Okada T, Kihara S, Funahashi T \& Shimomura I 2009 Blockade of mineralocorticoid receptor reverses adipocyte dysfunction and insulin resistance in obese mice. Cardiovascular Research 84 164-172. (https://doi. org/10.1093/cvr/cvp191)

Hirata A, Maeda N, Nakatsuji H, Hiuge-Shimizu A, Okada T, Funahashi T \& Shimomura I 2012 Contribution of glucocorticoidmineralocorticoid receptor pathway on the obesity-related adipocyte dysfunction. Biochemical and Biophysical Research Communications 419 182-187. (https://doi.org/10.1016/j.bbrc.2012.01.139)

Hoppmann J, Perwitz N, Meier B, Fasshauer M, Hadaschik D, Lehnert H \& Klein J 2010 The balance between gluco- and mineralo-corticoid action critically determines inflammatory adipocyte responses. Journal of Endocrinology 204 153-164. (https://doi.org/10.1677/JOE-09-0292)

Ibarrola J, Sadaba R, Martinez-Martinez E, Garcia-Peña A, Arrieta V, Alvarez V, Fernández-Celis A, Gainza A, Cachofeiro V, Santamaria E, et al. 2018 Aldosterone impairs mitochondrial function in human cardiac fibroblasts via A-kinase anchor protein 12. Scientific Reports $\mathbf{8}$ 6801. (https://doi.org/10.1038/s41598-018-25068-6)

Ingelsson E, Pencina MJ, Tofler GH, Benjamin EJ, Lanier KJ, Jacques PF, Fox CS, Meigs JB, Levy D, Larson MG, et al. 2007 Multimarker approach to evaluate the incidence of the metabolic syndrome and longitudinal changes in metabolic risk factors: the Framingham Offspring Study. Circulation 116 984-992. (https://doi.org/10.1161/ CIRCULATIONAHA.107.708537)

Jimenez M, Barbatelli G, Allevi R, Cinti S, Seydoux J, Giacobino JP, Muzzin P \& Preitner F 2003 Beta 3-adrenoceptor knockout in C57BL/6J mice depresses the occurrence of brown adipocytes in white fat. European Journal of Biochemistry 270 699-705. (https://doi. org/10.1046/j.1432-1033.2003.03422.x)

Joe AWB, Yi L, Even Y, Vogl AW \& Rossi FMV 2009 Depot-specific differences in adipogenic progenitor abundance and proliferative response to high-fat diet. Stem Cells 27 2563-2570. (https://doi. org/10.1002/stem.190)

Johnson F \& Giulivi C 2005 Superoxide dismutases and their impact upon human health. Molecular Aspects of Medicine 26 340-352. (https://doi.org/S0098-2997(05)00036-1)

Kalupahana NS \& Moustaid-Moussa N 2012 The adipose tissue reninangiotensin system and metabolic disorders: a review of molecular mechanisms. Critical Reviews in Biochemistry and Molecular Biology 47 379-390. (https://doi.org/10.3109/10409238.2012.694843)

Kershaw EE \& Flier JS 2004 Adipose tissue as an endocrine organ. Journal of Clinical Endocrinology and Metabolism 89 2548-2556. (https://doi. org/10.1210/jc.2004-0395)

Ketonen J, Shi J, Martonen E \& Mervaala E 2010 Periadventitial adipose tissue promotes endothelial dysfunction via oxidative stress in diet-induced obese C57Bl/6 mice. Circulation Journal 74 1479-1487. (https://doi.org/10.1253/circj.CJ-09-0661)

Kim J-A, Wei Y \& Sowers JR 2008 Role of mitochondrial dysfunction in insulin resistance. Circulation Research 102 401-414. (https://doi. org/10.1161/CIRCRESAHA.107.165472)

Kim S, Jin Y, Choi Y \& Park T 2011 Resveratrol exerts anti-obesity effects via mechanisms involving down-regulation of adipogenic and inflammatory processes in mice. Biochemical Pharmacology $\mathbf{8 1}$ 1343-1351. (https://doi.org/10.1016/j.bcp.2011.03.012)

Kim JI, Huh JY, Sohn JH, Choe SS, Lee YS, Lim CY, Jo A, Park SB, Han W \& Kim JB 2015 Lipid-overloaded enlarged adipocytes provoke insulin resistance independent of inflammation. Molecular and Cellular Biology 35 1686-1699. (https://doi.org/10.1128/MCB.01321-14)

Kim EN, Lim JH, Kim MY, Ban TH, Jang IA, Yoon HE, Park CW, Chang YS \& Choi BS 2018 Resveratrol, an Nrf2 activator, ameliorates agingrelated progressive renal injury. Aging 10 83-99. (https://doi. org/10.18632/agibg.101361)

Kimura S, Zhang G-X, Nishiyama A, Shokoji T, Yao L, Fan Y-Y, Rahman M \& Abe Y 2005 Mitochondria-derived reactive oxygen species and vascular MAP kinases: comparison of angiotensin II and diazoxide. Hypertension 45 438-444. (https://doi.org/10.1161/01. HYP.0000157169.27818.ae)

Korshunov SS, Skulachev VP \& Starkov AA 1997 High protonic potential actuates a mechanism of production of reactive oxygen species in mitochondria. FEBS Letters 416 15-18. (https://doi.org/10.1016/ S0014-5793(97)01159-9)

Kosacka J, Kern M, Klöting N, Paeschke S, Rudich A, Haim Y, Gericke M, Serke H, Stumvoll M, Bechmann I, et al. 2015 Autophagy in adipose tissue of patients with obesity and type 2 diabetes. Molecular and Cellular Endocrinology 409 21-32. (https://doi.org/10.1016/j. mce.2015.03.015)

Ku CR \& Lee EJ 2016 Response: the effects of high fat diet and resveratrol on mitochondrial activity of brown adipocytes (Endocrinol Metab 2016;31:328-35, Cheol Ryong Ku et al.). Endocrinology and Metabolism 31 482-483. (https://doi.org/10.3803/EnM.2016.31.3.482)

Kusminski CM \& Scherer PE 2012 Mitochondrial dysfunction in white adipose tissue. Trends in Endocrinology and Metabolism 23 435-443. (https://doi.org/10.1016/j.tem.2012.06.004)

Lagouge M, Argmann C, Gerhart-Hines Z, Meziane H, Lerin C, Daussin F, Messadeq N, Milne J, Lambert P, Elliott P, et al. 2006 Resveratrol improves mitochondrial function and protects against metabolic disease by activating SIRT1 and PGC-1alpha. Cell 127 1109-1122. (https://doi.org/10.1016/j.cell.2006.11.013)

Lee M-J \& Fried SK 2014 The glucocorticoid receptor, not the mineralocorticoid receptor, plays the dominant role in adipogenesis and adipokine production in human adipocytes. International Journal of Obesity 38 1228-1233. (https://doi.org/10.1038/ijo.2014.6)

Lee H, Lee YJ, Choi H, Ko EH \& Kim JW 2009 Reactive oxygen species facilitate adipocyte differentiation by accelerating mitotic clonal expansion. Journal of Biological Chemistry 284 10601-10609. (https:// doi.org/10.1074/jbc.M808742200)

Lee M-J, Pramyothin P, Karastergiou K \& Fried SK 2014 Deconstructing the roles of glucocorticoids in adipose tissue biology and the development of central obesity. Biochimica et Biophysica Acta 1842 473-481. (https://doi.org/10.1016/j.bbadis.2013.05.029)

Li A, Zhang S, Li J, Liu K, Huang F \& Liu B 2016 Metformin and resveratrol inhibit Drp1-mediated mitochondrial fission and prevent ER stress-associated NLRP3 inflammasome activation in the adipose
(C) 2018 Society for Endocrinology Published by Bioscientifica Ltd. Printed in Great Britain 
tissue of diabetic mice. Molecular and Cellular Endocrinology 434 36-47. (https://doi.org/10.1016/j.mce.2016.06.008)

Li G, Xie C, Lu S, Nichols RG, Tian Y, Li L, Patel D, Ma Y, Brocker CN, Yan T, et al. 2017 Intermittent fasting promotes white adipose browning and decreases obesity by shaping the gut microbiota. Cell Metabolism 26 672.e4-685.e4. (https://doi.org/10.1016/j. cmet.2017.08.019)

Li X \& Kazgan N 2011 Mammalian sirtuins and energy metabolism. International Journal of Biological Sciences 7 575-587.

Liu X, Wang S, You Y, Meng M, Zheng Z, Dong M, Lin J, Zhao Q, Zhang C, Yuan X, et al. 2015 Brown adipose tissue transplantation reverses obesity in Ob/Ob mice. Endocrinology 156 2461-2469. (https://doi.org/10.1210/en.2014-1598)

Lombès M, Oblin ME, Gasc JM, Baulieu EE, Farman N \& Bonvalet JP 1992 Immunohistochemical and biochemical evidence for a cardiovascular mineralocorticoid receptor. Circulation Research 71 503-510. (https:// doi.org/10.1161/01.RES.71.3.503)

Lowell BB, S-Susulic V, Hamann A, Lawitts JA, Himms-Hagen J, Boyer BB, Kozak LP \& Flier JS 1993 Development of obesity in transgenic mice after genetic ablation of brown adipose tissue. Nature 366 740-742. (https://doi.org/10.1038/366740a0)

Lumeng CN, Bodzin JL \& Saltiel AR 2007 Obesity induces a phenotypic switch in adipose tissue macrophage polarization. Journal of Clinical Investigation 117 175-184. (https://doi.org/10.1172/JCI29881)

Luo P, Dematteo A, Wang Z, Zhu L, Wang A, Kim H-S, Pozzi A, Stafford JM \& Luther JM 2013 Aldosterone deficiency prevents highfat-feeding-induced hyperglycaemia and adipocyte dysfunction in mice. Diabetologia 56 901-910. (https://doi.org/10.1007/s00125-0122814-8)

Luo T, Nocon A, Fry J, Sherban A, Rui X, Jiang B, Xu XJ, Han J, Yan Y, Yang Q, et al. 2016 AMPK activation by metformin suppresses abnormal extracellular matrix remodeling in adipose tissue and ameliorates insulin resistance in obesity. Diabetes 65 2295-2310. (https://doi.org/10.2337/db15-1122)

Luther JM 2014 Effects of aldosterone on insulin sensitivity and secretion. Steroids 91 54-60. (https://doi.org/10.1016/j.steroids.2014.08.016)

Luther JM, Luo P, Kreger MT, Brissova M, Dai C, Whitfield TT, Kim HS, Wasserman DH, Powers AC \& Brown NJ 2011 Aldosterone decreases glucose-stimulated insulin secretion in vivo in mice and in murine islets. Diabetologia 54 2152-2163. (https://doi.org/10.1007/s00125011-2158-9)

Ma Q 2013 Role of nrf2 in oxidative stress and toxicity. Annual Review of Pharmacology and Toxicology 53 401-426. (https://doi.org/10.1146/ annurev-pharmtox-011112-140320)

Malnick SDH \& Knobler H 2006 The medical complications of obesity. QJM: An International Journal of Medicine 99 565-579. (https://doi. org/10.1093/qjmed/hcl085)

Manna P \& Jain SK 2015 Obesity, oxidative stress, adipose tissue dysfunction, and the associated health risks: causes and therapeutic strategies. Metabolic Syndrome and Related Disorders 13 423-444. (https://doi.org/10.1089/met.2015.0095)

Marchesi C, Ebrahimian T, Angulo O, Paradis P \& Schiffrin EL 2009 Endothelial nitric oxide synthase uncoupling and perivascular adipose oxidative stress and inflammation contribute to vascular dysfunction in a rodent model of metabolic syndrome. Hypertension 54 1384-1392. (https://doi.org/10.1161/ HYPERTENSIONAHA.109.138305)

Marzolla V, Armani A, Feraco A, De Martino MU, Fabbri A, Rosano G \& Caprio M 2014 Mineralocorticoid receptor in adipocytes and macrophages: a promising target to fight metabolic syndrome. Steroids 91 46-53. (https://doi.org/10.1016/j.steroids.2014.05.001)

McLaughlin T, Lamendola C, Liu A \& Abbasi F 2011 Preferential fat deposition in subcutaneous versus visceral depots is associated with insulin sensitivity. Journal of Clinical Endocrinology and Metabolism 96 E1756-E1760. (https://doi.org/10.1210/jc.2011-0615)
Mitsuishi M, Miyashita K, Muraki A \& Itoh H 2009 Angiotensin II reduces mitochondrial content in skeletal muscle and affects glycemic control. Diabetes 58 710-717. (https://doi.org/10.2337/ db08-0949)

Miwa S \& Brand MD 2003 Mitochondrial matrix reactive oxygen species production is very sensitive to mild uncoupling. Biochemical Society Transactions 31 1300-1301. (https://doi.org/10.1042/)

Miyazaki R, Ichiki T, Hashimoto T, Inanaga K, Imayama I, Sadoshima J \& Sunagawa K 2008 SIRT1, a longevity gene, downregulates angiotensin II type 1 receptor expression in vascular smooth muscle cells. Arteriosclerosis, Thrombosis, and Vascular Biology 28 1263-1269. (https://doi.org/10.1161/ATVBAHA.108.166991)

Montgomery MK \& Turner N 2014 Mitochondrial dysfunction and insulin resistance: an update. Endocrine Connections 4 R1-R15. (https://doi.org/10.1530/EC-14-0092)

Mummidi S, Das NA, Carpenter AJ, Kandikattu H, Krenz M, Siebenlist U, Valente AJ \& Chandrasekar B 2016 Metformin inhibits aldosteroneinduced cardiac fibroblast activation, migration and proliferation in vitro, and reverses aldosterone+salt-induced cardiac fibrosis in vivo. Journal of Molecular and Cellular Cardiology 98 95-102. (https://doi. org/10.1016/j.yjmcc.2016.07.006)

Nagase M \& Fujita T 2009 Mineralocorticoid receptor activation in obesity hypertension. Hypertension Research 32 649-657. (https://doi. org/10.1038/hr.2009.86)

Nedergaard J \& Cannon B 2014 The browning of white adipose tissue: some burning issues. Cell Metabolism 20 396-407. (https://doi. org/10.1016/j.cmet.2014.07.005)

Nguyen Dinh Cat A \& Jaisser F 2012 Extrarenal effects of aldosterone. Current Opinion in Nephrology and Hypertension 21 147-156. (https:// doi.org/10.1097/MNH.0b013e32834fb25b)

Nguyen Dinh Cat A, Antunes TT, Callera GE, Sanchez A, Tsiropoulou S, Dulak-Lis MG, Anagnostopoulou A, He Y, Montezano AC, Jaisser F, et al. 2016 Adipocyte-specific mineralocorticoid receptor overexpression in mice is associated with metabolic syndrome and vascular dysfunction: role of redox-sensitive PKG-1 and Rho kinase. Diabetes 65 2392-2403. (https://doi.org/10.2337/db151627)

Nguyen Dinh Cat A, Callera GE, Friederich-Persson M, Sanchez A, Dulak-Lis MG, Tsiropoulou S, Montezano AC, He Y, Briones AM, Jaisser F, et al. 2018 Vascular dysfunction in obese diabetic $\mathrm{db} / \mathrm{db}$ mice involves the interplay between aldosterone/mineralocorticoid receptor and Rho kinase signaling. Scientific Reports 8 2952. (https:// doi.org/10.1038/s41598-018-21087-5)

Nishimura S, Manabe I, Nagasaki M, Eto K, Yamashita H, Ohsugi M, Otsu M, Hara K, Ueki K, Sugiura S, et al. 2009 CD8+ effector T cells contribute to macrophage recruitment and adipose tissue inflammation in obesity. Nature Medicine 15 914-920. (https://doi. org/10.1038/nm.1964)

Nisoli E, Clementi E, Carruba MO \& Moncada S 2007 Defective mitochondrial biogenesis: a hallmark of the high cardiovascular risk in the metabolic syndrome? Circulation Research 100 795-806. (https://doi.org/10.1161/01.RES.0000259591.97107.6c)

Nogueiras R, Habegger KM, Chaudhary N, Finan B, Banks AS, Dietrich MO, Horvath TL, Sinclair DA, Pfluger PT \& Tschöp MH 2012 Sirtuin 1 and sirtuin 3: physiological modulators of metabolism. Physiological Reviews 92 1479-1514. (https://doi.org/10.1152/ physrev.00022.2011)

Oliveira Andrade JM, Paraíso AF, Garcia ZM, Ferreira AVM, Sinisterra RDM, Sousa FB, Guimarães ALS, de Paula AMB, Campagnole-Santos MJ, dos Santos RA, et al. 2014 Cross talk between angiotensin-(1-7)/Mas axis and sirtuins in adipose tissue and metabolism of high-fat feed mice. Peptides 55 158-165. (https://doi. org/10.1016/j.peptides.2014.03.006)

Palacios S, Foidart J-M \& Genazzani AR 2006 Advances in hormone replacement therapy with drospirenone, a unique progestogen with
() 2018 Society for Endocrinology Published by Bioscientifica Ltd. Printed in Great Britain 
aldosterone receptor antagonism. Maturitas 55 297-307. (https://doi. org/10.1016/j.maturitas.2006.07.009)

Pearce P \& Funder JW 1987 High affinity aldosterone binding sites (type I receptors) in rat heart. Clinical and Experimental Pharmacology and Physiology 14 859-866.

Pi J, Leung L, Xue P, Wang W, Hou Y, Liu D, Yehuda-Shnaidman E, Lee C, Lau J, Kurtz TW, et al. 2010 Deficiency in the nuclear factor E2-related factor-2 transcription factor results in impaired adipogenesis and protects against diet-induced obesity. Journal of Biological Chemistry 285 9292-9300. (https://doi.org/10.1074/jbc.M109.093955)

Pischon T, Boeing H, Hoffmann K, Bergmann M, Schulze MB, Overvad K, van der Schouw YT, Spencer E, Moons KGM, Tjønneland A, et al. 2008 General and abdominal adiposity and risk of death in Europe. New England Journal of Medicine 359 2105-2120. (https://doi.org/10.1056/ NEJMoa0801891)

Poher A-L, Altirriba J, Veyrat-Durebex C \& Rohner-Jeanrenaud F 2015 Brown adipose tissue activity as a target for the treatment of obesity/ insulin resistance. Frontiers in Physiology 6. (https://doi.org/10.3389/ fphys.2015.00004)

Preston RA, Norris PM, Alonso AB, Ni P, Hanes V \& Karara AH 2007 Randomized, placebo-controlled trial of the effects of drospirenoneestradiol on blood pressure and potassium balance in hypertensive postmenopausal women receiving hydrochlorothiazide. Menopause $\mathbf{1 4}$ 408-414. (https://doi.org/10.1097/01.gme.0000243572.63322.f7)

Price NL, Gomes AP, Ling AJY, Duarte FV, Martin-Montalvo A, North BJ, Agarwal B, Ye L, Ramadori G, Teodoro JS, et al. 2012 SIRT1 is required for AMPK activation and the beneficial effects of resveratrol on mitochondrial function. Cell Metabolism 15 675-690. (https://doi. org/10.1016/j.cmet.2012.04.003)

Queisser N, Oteiza PI, Link S, Hey V, Stopper H \& Schupp N 2014 Aldosterone activates transcription factor Nrf2 in kidney cells both in vitro and in vivo. Antioxidants and Redox Signaling $212126-2142$. (https://doi.org/10.1089/ars.2013.5565)

Ramalingam L, Menikdiwela K, LeMieux M, Dufour JM, Kaur G, Kalupahana N \& Moustaid-Moussa N 2017 The renin angiotensin system, oxidative stress and mitochondrial function in obesity and insulin resistance. Biochimica et Biophysica Acta (BBA): Molecular Basis of Disease 1863 1106-1114. (https://doi.org/10.1016/j. bbadis.2016.07.019)

Rogge MM 2009 The role of impaired mitochondrial lipid oxidation in obesity. Biological Research For Nursing 10 356-373. (https://doi. org/10.1177/1099800408329408)

Ronconi V, Turchi F, Appolloni G, di Tizio V, Boscaro M \& Giacchetti G 2012 Aldosterone, mineralocorticoid receptor and the metabolic syndrome: role of the mineralocorticoid receptor antagonists. Current Vascular Pharmacology 10 238-246. (https://doi. org/10.2174/157016112799304969)

Rondinone CM, Rodbard D \& Baker ME 1993 Aldosterone stimulated differentiation of mouse 3T3-L1 cells into adipocytes. Endocrinology 132 2421-2426. (https://doi.org/10.1210/endo.132.6.8504747)

Rong JX, Qiu Y, Hansen MK, Zhu L, Zhang V, Xie M, Okamoto Y, Mattie MD, Higashiyama H, Asano S, et al. 2007 Adipose mitochondrial biogenesis is suppressed in $\mathrm{db} / \mathrm{db}$ and high-fat diet-fed mice and improved by rosiglitazone. Diabetes 56 1751-1760. (https:// doi.org/10.2337/db06-1135)

Rossi G-P, Sechi LA, Giacchetti G, Ronconi V, Strazzullo P \& Funder JW 2008 Primary aldosteronism: cardiovascular, renal and metabolic implications. Trends in Endocrinology and Metabolism 19 88-90. (https://doi.org/10.1016/j.tem.2008.01.006)

Ruderman NB, Julia Xu X, Nelson L, Cacicedo JM, Saha AK, Lan F \& Ido Y 2010 AMPK and SIRT1: a long-standing partnership? American Journal of Physiology: Endocrinology and Metabolism 298 E751-E760. (https:// doi.org/10.1152/ajpendo.00745.2009)

Santos L, Escande C \& Denicola A 2016 Potential modulation of sirtuins by oxidative stress. Oxidative Medicine and Cellular Longevity 2016 9831825. (https://doi.org/10.1155/2016/9831825)
Schiffrin EL \& Touyz RM 2004 From bedside to bench to bedside: role of renin-angiotensin-aldosterone system in remodeling of resistance arteries in hypertension. American Journal of Physiology: Heart and Circulatory Physiology 287 H435-H446. (https://doi.org/10.1152/ ajpheart.00262.2004)

Schneider K, Valdez J, Nguyen J, Vawter M, Galke B, Kurtz TW \& Chan JY 2016 Increased energy expenditure, Ucp 1 expression, and resistance to diet-induced obesity in mice lacking nuclear factor-erythroid-2related transcription factor-2 (Nrf2). Journal of Biological Chemistry 291 7754-7766. (https://doi.org/10.1074/jbc.M115.673756)

Shimizu I \& Walsh K 2015 The whitening of brown fat and its implications for weight management in obesity. Current Obesity Reports 4 224-229. (https://doi.org/10.1007/s13679-015-0157-8)

Shimizu I, Aprahamian T, Kikuchi R, Shimizu A, Papanicolaou KN, MacLauchlan S, Maruyama S \& Walsh K 2014 Vascular rarefaction mediates whitening of brown fat in obesity. Journal of Clinical Investigation 124 2099-2112. (https://doi.org/10.1172/JCI71643)

Shin S, Wakabayashi J, Yates MS, Wakabayashi N, Dolan PM, Aja S, Liby KT, Sporn MB, Yamamoto M \& Kensler TW 2009 Role of Nrf2 in prevention of high-fat diet-induced obesity by synthetic triterpenoid CDDO-imidazolide. European Journal of Pharmacology 620 138-144. (https://doi.org/10.1016/j.ejphar.2009.08.022)

Silva KAS, Delafontaine P \& Yoshida T 2017 Angiotensin II deregulates mitochondrial quality control and prevents autophagosome formation in skeletal muscle. Poster presented at the Health Sciences Research Day, University of Missouri, Columbia, 2017.

Simon AR, Rai U, Fanburg BL \& Cochran BH 1998 Activation of the JAK-STAT pathway by reactive oxygen species. American Journal of Physiology 275 C1640-C1652. (https://doi.org/10.1152/ ajpcell.1998.275.6.C1640)

Sivitz WI \& Yorek MA 2010 Mitochondrial dysfunction in diabetes: from molecular mechanisms to functional significance and therapeutic opportunities. Antioxidants and Redox Signaling 12 537-577. (https:// doi.org/10.1089/ars.2009.2531)

Spiegelman BM \& Flier JS 1996 Adipogenesis and obesity: rounding out the big picture. Cell 87 377-389. (https://doi.org/10.1016/S00928674(00)81359-8)

Stanford KI, Middelbeek RJW \& Goodyear LJ 2015 Exercise effects on white adipose tissue: beiging and metabolic adaptations. Diabetes 64 2361-2368. (https://doi.org/10.2337/db15-0227)

Stuck BJ, Lenski M, Böhm M \& Laufs U 2008 Metabolic Switch and hypertrophy of cardiomyocytes following treatment with angiotensin II are prevented by AMP-activated protein kinase. Journal of Biological Chemistry 283 32562-32569. (https://doi.org/10.1074/jbc. M801904200)

Talukdar S, Oh DY, Bandyopadhyay G, Li D, Xu J, McNelis J, Lu M, Li P, Yan Q, Zhu Y, et al. 2012 Neutrophils mediate insulin resistance in mice fed a high-fat diet through secreted elastase. Nature Medicine $\mathbf{1 8}$ 1407-1412. (https://doi.org/10.1038/nm.2885)

Tankó LB \& Christiansen C 2005 Effects of 17beta-oestradiol plus different doses of drospirenone on adipose tissue, adiponectin and atherogenic metabolites in postmenopausal women. Journal of Internal Medicine 258 544-553. (https://doi.org/10.1111/j.13652796.2005.01571.x)

Taylor D \& Gottlieb RA 2017 Parkin-mediated mitophagy is downregulated in browning of white adipose tissue. Obesity $\mathbf{2 5}$ 704-712. (https://doi.org/10.1002/oby.21786)

Tchkonia T, Thomou T, Zhu Y, Karagiannides I, Pothoulakis C, Jensen MD \& Kirkland JL 2013 Mechanisms and metabolic implications of regional differences among fat depots. Cell Metabolism 17 644-656. (https://doi.org/10.1016/j.cmet.2013.03.008)

Thalmann S \& Meier CA 2007 Local adipose tissue depots as cardiovascular risk factors. Cardiovascular Research 75 690-701. (https://doi.org/10.1016/j.cardiores.2007.03.008)

Than A, Xu S, Li R, Leow M-S, Sun L \& Chen P 2017 Angiotensin type 2 receptor activation promotes browning of white adipose tissue and 
brown adipogenesis. Signal Transduction and Targeted Therapy 217022 (https://doi.org/10.1038/sigtrans.2017.22)

Thatcher S, Yiannikouris F, Gupte M \& Cassis L 2009 The adipose reninangiotensin system. Molecular and Cellular Endocrinology 302 111-117. (https://doi.org/10.1016/j.mce.2009.01.019)

Thyagarajan B \& Foster MT 2017 Beiging of white adipose tissue as a therapeutic strategy for weight loss in humans. Hormone Molecular Biology and Clinical Investigation 31 20170016. (https://doi. org/10.1515/hmbci-2017-0016)

Tilg H \& Moschen AR 2006 Adipocytokines: mediators linking adipose tissue, inflammation and immunity. Nature Reviews Immunology 6 772-783. (https://doi.org/10.1038/nri1937)

Timmers S, Konings E, Bilet L, Houtkooper RH, van de Weijer T, Goossens GH, Hoeks J, van der Krieken S, Ryu D, Kersten S, et al. 2011 Calorie restriction-like effects of 30 days of resveratrol supplementation on energy metabolism and metabolic profile in obese humans. Cell Metabolism 14 612-622. (https://doi. org/10.1016/j.cmet.2011.10.002)

Tirosh A, Garg R \& Adler GK 2010 Mineralocorticoid receptor antagonists and the metabolic syndrome. Current Hypertension Reports 12 252-257. (https://doi.org/10.1007/s11906-010-0126-2)

Tormos KV, Anso E, Hamanaka RB, Eisenbart J, Joseph J, Kalyanaraman B \& Chandel NS 2011 Mitochondrial complex III ROS regulate adipocyte differentiation. Cell Metabolism 14 537-544. (https://doi. org/10.1016/j.cmet.2011.08.007)

Trayhurn P \& Beattie JH 2001 Physiological role of adipose tissue: white adipose tissue as an endocrine and secretory organ. Proceedings of the Nutrition Society 60 329-339. (https://doi.org/10.1079/PNS200194)

Um J-H, Park S-J, Kang H, Yang S, Foretz M, McBurney MW, Kim MK, Viollet B \& Chung JH 2010 AMP-activated protein kinase-deficient mice are resistant to the metabolic effects of resveratrol. Diabetes $\mathbf{5 9}$ 554-563. (https://doi.org/10.2337/db09-0482)

Urbanet R, Nguyen Dinh Cat A, Feraco A, Venteclef N, El Mogrhabi S, Sierra-Ramos C, Alvarez de la Rosa D, Adler GK, Quilliot D, Rossignol P, et al. 2015 Adipocyte mineralocorticoid receptor activation leads to metabolic syndrome and induction of prostaglandin D2 synthase. Hypertension 66 149-157. (https://doi. org/10.1161/HYPERTENSIONAHA.114.04981)

Ursini F, Maiorino M, Brigelius-Flohe R, Aumann KD, Roveri A, Schomburg D \& Flohe L 1995 Diversity of glutathione peroxidases. Methods in Enzymology 252 38-53.

Vaidya A, Underwood PC, Hopkins PN, Jeunemaitre X, Ferri C, Williams GH \& Adler GK 2013 Abnormal aldosterone physiology and cardiometabolic risk factors. Hypertension 61 886-893. (https://doi. org/10.1161/HYPERTENSIONAHA.111.00662)

van Marken Lichtenbelt WD, Vanhommerig JW, Smulders NM, Drossaerts JMAFL, Kemerink GJ, Bouvy ND, Schrauwen P \& Teule GJJ 2009 Cold-activated brown adipose tissue in healthy men. New England Journal of Medicine 360 1500-1508. (https://doi.org/10.1056/ NEJMoa0808718)

Villena JA, Viollet B, Andreelli F, Kahn A, Vaulont S \& Sul HS 2004 Induced adiposity and adipocyte hypertrophy in mice lacking the AMP-activated protein kinase- $\alpha 2$ subunit. Diabetes 53 2242-2249. (https://doi.org/10.2337/diabetes.53.9.2242)

Wada T, Ohshima S, Fujisawa E, Koya D, Tsuneki H \& Sasaoka T 2009 Aldosterone inhibits insulin-induced glucose uptake by degradation of insulin receptor substrate (IRS) 1 and IRS2 via a reactive oxygen species-mediated pathway in 3T3-L1 adipocytes. Endocrinology 150 1662-1669. (https://doi.org/10.1210/en.2008-1018)

Wada T, Kenmochi H, Miyashita Y, Sasaki M, Ojima M, Sasahara M, Koya D, Tsuneki H \& Sasaoka T 2010 Spironolactone improves glucose and lipid metabolism by ameliorating hepatic steatosis and inflammation and suppressing enhanced gluconeogenesis induced by high-fat and high-fructose diet. Endocrinology $1512040-2049$. (https://doi.org/10.1210/en.2009-0869)
Wagner G, Lindroos-Christensen J, Einwallner E, Husa J, Zapf TC, Lipp K, Rauscher S, Groger M, Spittler A, Loewe R, et al. 2017 HO-1 inhibits preadipocyte proliferation and differentiation at the onset of obesity via ROS dependent activation of Akt2. Scientific Reports 740881. (https://doi.org/10.1038/srep40881)

Wajchenberg BL 2000 Subcutaneous and visceral adipose tissue: their relation to the metabolic syndrome. Endocrine Reviews 21 697-738. (https://doi.org/10.1210/edrv.21.6.0415)

Wang C-H, Wang C-C, Huang H-C \& Wei Y-H 2013 Mitochondrial dysfunction leads to impairment of insulin sensitivity and adiponectin secretion in adipocytes. FEBS Journal 280 1039-1050. (https://doi.org/10.1111/febs.12096)

Wang S, Liang X, Yang Q, Fu X, Rogers CJ, Zhu M, Rodgers BD, Jiang Q, Dodson MV \& Du M 2015 Resveratrol induces brown-like adipocyte formation in white fat through activation of AMP-activated protein kinase (AMPK) $\alpha 1$. International Journal of Obesity 39 967-976. (https:// doi.org/10.1038/ijo.2015.23)

Wankhade UD, Shen M, Yadav H \& Thakali KM 2016 Novel browning agents, mechanisms, and therapeutic potentials of brown adipose tissue. BioMed Research International 2016 2365609. (https://doi. org/10.1155/2016/2365609)

Wassmann S, Wassmann K \& Nickenig G 2006 Regulation of antioxidant and oxidant enzymes in vascular cells and implications for vascular disease. Current Hypertension Reports 8 69-78. (https://doi.org/10.1007/ s11906-006-0043-6)

Whaley-Connell A, Johnson MS \& Sowers JR 2010 Aldosterone: role in the cardiometabolic syndrome and resistant hypertension. Progress in Cardiovascular Diseases 52 401-409. (https://doi.org/10.1016/j. pcad.2009.12.004)

White WB, Pitt B, Preston RA \& Hanes V 2005 Antihypertensive effects of drospirenone with 17beta-estradiol, a novel hormone treatment in postmenopausal women with stage 1 hypertension. Circulation 112 1979-1984. (https://doi.org/10.1161/CIRCULATIONAHA.104.501502)

White WB, Hanes V, Chauhan V \& Pitt B 2006 Effects of a new hormone therapy, drospirenone and 17-beta-estradiol, in postmenopausal women with hypertension. Hypertension 48 246-253. (https://doi. org/10.1161/01.HYP.0000232179.60442.84)

White A, Cat AND, Montezano A, Salt I \& Touyz R 2015 Activators of AMP-activated protein kinase regulate adipocyte aldosterone secretion and mineralocorticoid receptor signalling. Endocrine Abstracts $\mathbf{3 7}$ OC5.3. (https://doi.org/10.1530/endoabs.37.OC5.3)

Winer DA, Winer S, Shen L, Wadia PP, Yantha J, Paltser G, Tsui H, Wu P, Davidson MG, Alonso MN, et al. 2011 B cells promote insulin resistance through modulation of $\mathrm{T}$ cells and production of pathogenic IgG antibodies. Nature Medicine 17 610-617. (https://doi. org/10.1038/nm.2353)

Wu J, Boström P, Sparks LM, Ye L, Choi JH, Giang A-H, Khandekar M, Virtanen KA, Nuutila P, Schaart G, et al. 2012 Beige adipocytes are a distinct type of thermogenic fat cell in mouse and human. Cell $\mathbf{1 5 0}$ 366-376. (https://doi.org/10.1016/j.cell.2012.05.016)

Xu XJ, Gauthier M-S, Hess DT, Apovian CM, Cacicedo JM, Gokce N, Farb M, Valentine RJ \& Ruderman NB 2012 Insulin sensitive and resistant obesity in humans: AMPK activity, oxidative stress, and depot-specific changes in gene expression in adipose tissue. Journal of Lipid Research 53 792-801. (https://doi.org/10.1194/jlr.P022905)

Yang Y-K, Chen M, Clements RH, Abrams GA, Aprahamian CJ \& Harmon CM 2008 Human mesenteric adipose tissue plays unique role versus subcutaneous and omental fat in obesity related diabetes. Cellular Physiology and Biochemistry 22 531-538. (https://doi. org/10.1159/000185527)

Yang K-K, Sui Y, Zhou H-R, Shen J, Tan N, Huang Y-M, Li S-S, Pan Y-H, Zhang X-X \& Zhao H-L 2016 Cross-talk between AMP-activated protein kinase and renin-angiotensin system in uninephrectomised rats. Journal of the Renin-Angiotensin-Aldosterone System 17. (https://doi. org/10.1177/1470320316673231)
๑) 2018 Society for Endocrinology Published by Bioscientifica Ltd. Printed in Great Britain 
Yu Z, Shao W, Chiang Y, Foltz W, Zhang Z, Ling W, Fantus IG \& Jin T 2011 Oltipraz upregulates the nuclear factor (erythroid-derived 2)-like 2 (corrected) (NRF2) antioxidant system and prevents insulin resistance and obesity induced by a high-fat diet in C57BL/6J mice. Diabetologia 54 922-934. (https://doi.org/10.1007/s00125-010-2001-8)

Zennaro M-C, Caprio M \& Fève B 2009 Mineralocorticoid receptors in the metabolic syndrome. Trends in Endocrinology and Metabolism 20 444-451. (https://doi.org/10.1016/j.tem.2009.05.006)
Zhang Y-KJ, Wu KC, Liu J \& Klaassen CD 2012 Nrf2 deficiency improves glucose tolerance in mice fed a high-fat diet. Toxicology and Applied Pharmacology 264 305-314. (https://doi.org/10.1016/j. taap.2012.09.014)

Zhu C, Huang S, Yuan Y, Ding G, Chen R, Liu B, Yang T \& Zhang A 2011 Mitochondrial dysfunction mediates aldosterone-induced podocyte damage: a therapeutic target of PPAR $\gamma$. American Journal of Pathology 178 2020-2031. (https://doi.org/10.1016/j.ajpath.2011.01.029)

Received in final form 16 May 2018

Accepted 6 June 2018

Accepted Preprint published online 6 June 2018 